\title{
Country Insurance and Corporate Risk-taking
}

\author{
Hui Tong (IMF) and Shang-Jin Wei (Columbia University, NBER)
}

November 18, 2010

\begin{abstract}
The paper presents a robust but previously undocumented data pattern: corporate risk taking is positively correlated with country-level foreign exchange reserve holdings (as a share of the GDP). With data on 5000 manufacturing firms in 24 emerging economies during 2000-2006, we show that foreign reserve accumulation is economically and statistically associated with higher leverage ratios, lower cash holdings, riskier investments, and higher total and idiosyncratic stock return volatilities. We further show that at least a part of the positive correlation is due to greater corporate risk taking in response to an improvement in a country's ability to defend against macroeconomic risks associated with a sudden stop in international capital flows. The pattern is stronger for firms that are intrinsically more dependent on external finance for working capital and capital expenditure. It continues to hold when the foreign reserve is instrumented by cumulative trade surpluses. Moreover, with reserve accumulation, the risk taking is more pronounced for domestically-owned firms or in countries with weak creditor rights. Our finding may provide an explanation for a puzzle during the 2008-2009 global crisis: that higher foreign reserve holdings before the crisis did not translate into less severe corporate difficulties across countries during the crisis.

Key words: foreign exchange reserve, corporate risk, financial crisis

JEL codes: F3, G2, G3

Contact Information: Hui Tong, International Monetary Fund, $70019^{\text {th }}$ St. NW, Washington, D.C. 20431, email: htong@imf.org; Shang-Jin Wei, Graduate School of Business, Columbia University, 619 Uris Hall, 3022 Broadway, New York, NY 10027; e-mail: shangjin.wei@columbia.edu, webpage: www.nber.org/ wei. We thank Kenza Benhima, Stijn Claessens, Gian Maria Milesi-Ferretti, Linda Goldberg, Hiro Ito, Luc Laeven, Jaewoo Lee, Kai Li, David Romer, Rene Stulz, Sheridan Titman, Yishay Yafeh, and seminar participants at the IMF, Federal Reserve Bank of New York, Conference on Financial Globalization at Banco de España, and Conference on Emerging Market Finance at Tsinghua University, NBER Summer Institute, and Summer Conference on Finance at the India School of Business for helpful comments and Joy Glazener for research assistance. The views in the paper are those of the authors, and do not necessarily reflect those of the IMF.
\end{abstract}




\section{Introduction}

While the literature on corporate risk-taking is vast, there have been comparatively few studies on the effects of government policies on corporate finance. This paper investigates how corporate risk-taking behavior may be affected by a country's defensive strategies against sudden stops in international capital flows.

The 2008-2009 global financial crisis provides a recent motivation for such research. In the years leading up to the global crisis, many countries have accumulated a vast sum of foreign exchange reserves (see Figure 1). A key intent of the accumulation for many countries is to build up a cushion against external negative shocks, such as the sudden reversal of international capital flows that was experienced by many emerging market economies in Asia and Latin America during 1997-2000 (Obstfeld et al. 2009). To the extent that a higher FX reserve makes a country less likely to suffer a balance-of-payments crisis, corporations should experience less default events. Somewhat surprisingly, according to IMF chief economist Olivier Blanchard, when another reversal of international capital flows did come in 2008-2009, the reserve holdings didn't appear to lessen the severity of the crisis for the countries in question. A scatter plot of the size of recession as measured by the decline in GDP growth and the ratio of FX reserve to GDP prior to the crisis (Figure 2, imported from Blanchard et al, 2009) does not reveal a negative relationship. ${ }^{1}$

While the lack of a negative relationship could potentially be explained by several possibilities, in this paper we investigate a particular hypothesis that is anchored to corporate financial behavior. In particular, we examine whether an increase in country-level insurance as measured by an increase in reserve/GDP ratio could induce corporations to respond by raising their risk-taking and hence increasing their vulnerability to a negative shock. As a result, when a large negative shock actually arrives (such as a massive reversal of global capital flows in 2008), the actual severity of the corporate financial difficulties in a country

\footnotetext{
${ }^{1}$ On the contrary, Frenkel and Saravelos (2010) used variables from the early warning literature to see if they could "predict" relative performance across countries during 2008-2009. They found reserve/GDP (and its variations) is a significant predictor, which seems to contradict Blanchard.
} 
with a high pre-crisis reserve/GDP ratio is not much better than their counterparts in a country with a lower reserve/GDP ratio.

We examine over 5000 listed firms in 24 emerging economies from 2000 to 2006. A robust pattern in the data is that firms in countries (or years) with a higher ratio of foreign exchange reserves to GDP tend to have a higher leverage ratio, a lower cash/asset ratio, riskier corporate investment, and higher total and idiosyncratic firm-level stock return volatility. We interpret these findings as evidence that corporate risk-taking goes up as the level of country insurance increases.

The correlation could reflect a mechanical association or even a reverse causality. For example, massive capital inflows into an emerging market economy (due to low interest rates in the United States and Europe) could inflate the leverage ratios in all corporations, and at the same time, raise the reserve/GDP ratio. To find out if the patterns reflect a causal relation from country insurance to corporate risk taking, we undertake two additional investigations. First, we include an additional regressor which is an interaction between a firm's intrinsic dependence on external finance and the country-level FX reserve/GDP ratio. The idea is that if a higher leverage ratio reflects active risk-taking by firms, we would expect that firms that are more constrained by external finance ex ante would raise their leverage ratios more aggressively ex post when the country insurance is perceived to be stronger. (In comparison, a mechanical correlation that does not involve firms actively re-optimizing their leverage ratios would only change the leverage ratios of all firms proportionately.)

Second, we implement an instrumental variable regression. As a matter of definition, a country's foreign exchange reserve accumulation is the sum of three components: cumulative trade surplus in goods and services, cumulative inflows of factor income (such as remittances of migrant workers' income and government transfers), and cumulative net inflows of capital (including foreign direct investment, portfolio debt and equity, bank loans, and trade credits). The reverse causality or the mechanical correlation stories are about the relationship between the last components of the reserve accumulation and corporate leverage ratios. We instrument a country's foreign exchange reserve by its cumulative trade surpluses in goods and services and find that the same patterns continue to hold. We control for the potential direct impact of international trade on corporate risk by including sectoral exports or focusing on sectors with little international trade. As trade might be correlated with capital 
flow, we further include variables capturing the liquidity environment that might be affected by capital flows, such as domestic credit/GDP and foreign debt/GDP.

Third, we examine some further asymmetric effect across firms within a country, based on whether the largest shareholder of the firm is domestic or foreign. We find that reserves increase risk taking more for domestically-owned firm than for foreign-owned ones. To the extent that domestically-owned firms have less access to international liquidity and may be more subject to liquidity shocks, this asymmetry further suggests that domestic firms take on additional risk in response to perceived decline of country risk.

Fourth, we examine asymmetry across countries. Firm risk-taking is also affected by the strength of the voice by stakeholders such as creditors and shareholders. The literature suggests that stronger creditor rights in bankruptcy reduce corporate risk-taking (see Acharya, Amihud and Litov (2009)). Hence, we examine whether the impact of reserve accumulation on risk-taking differs across countries based on the country's creditor rights. We find that given the same level of reserve accumulation, the increase of risk-taking is significantly smaller in countries with stronger creditor right protection.

These asymmetries across firms based on ownership and across countries based on creditor rights further suggest that there is some elements of causality behind the positive relationship between reserve accumulation and corporate risk taking.

Higher foreign reserve has been found to make currency crisis less likely, as shown in large literature including Frankel and Rose (1996). Moreover, there have been suggestions that the Asian financial crisis may have led many emerging market economies to want to increase foreign reserve so as to avoid having to go to the IMF. For example, in Foreign Affairs (1999), Martin Feldstein wrote "emerging markets must learn to inoculate themselves against future currency attacks by increasing liquidity, such as foreign currency reserves, so they can fight back the powerful forces of market speculation on their own. While self-help is expensive, it is far less painful than the turmoil of currency crises."

By reducing the likelihood of currency crisis, reserve accumulation alleviates two types of risks that firms are exposed to: foreign exchange risk (concerns of the domestic

\footnotetext{
${ }^{2}$ See "A Self Helping Guide for Emerging Markets", Foreign Affairs (March /April, 1999). http://www.foreignaffairs.com/articles/54801/martin-feldstein/a-self-help-guide-for-emerging-markets
} 
value of foreign sales and foreign liabilities) or liquidity risk (concerns for not being able to raise funds even domestically). The liquidity risk can occur when a country is under currency crisis, due to the twin banking and currency crisis phenomenon as documented in Kaminsky and Reinhart (1999). That is, when a currency crisis occurs, domestic banks may experience severe problems as well, which will put pressure on non-financial firm's funding cost even if these firms do not borrow directly from abroad. Hence Obstfeld, et. al. (2010) argue that reserves ensure liquidity at the time of liquidity shortage and reduce the likelihood of "double drain" (internal and external). In this paper, we focus on the liquidity risk. It would be ideal to also directly measure foreign exchange risk, but the lack of data on firm-level foreign liability hinders us from doing so.

Our paper does not regard corporate risk-taking as necessarily socially inefficient. There has been earlier work suggesting that risk-taking could increase firm's growth and value during normal times (e.g. Obstfeld (2004) and John, Litov, and Yeung (2008)). Instead, we argue that firm's risk-taking can increase their vulnerability to unexpected liquidity shocks such as the 2007-2008 global crisis. Indeed, Tong and Wei (2010) find that during this crisis, firms with high leverage experienced a more severe decline of stock price.

The paper is linked to four literatures. First, it is linked to a large literature on crosscountry capital structure, including Rajan and Zingales (1995), Booth, Demirgüç-Kunt and Maksimovic (2001) and Ağca, Nicolò and Detragiache (2007). Second, it is related to research on corporate risk taking (Claessens, Djankov and Nenova 2000; Coles, Daniel and Naveen, 2006; John, Litov, and Yeung, 2008; Laeven and Levin, 2009; Bartram, Brown and Stulz, 2009; Li et al (2010)). As far as we know, none of the papers in these two literatures has linked corporate risk-taking with country-level foreign reserve holdings. Third, our paper is linked to a subset of international finance/open economy macroeconomics literature on foreign reserve accumulation, such as Aizenman and Lee (2008), Jeanne and Rancière (2007) and Obstfeld et al. (2009). These papers do not examine the response by corporate finance variables to country insurance variables. Finally, our paper also relates to the early literature on exchange rate regimes, which argues that pegged exchange rate regime serves as an implicit exchange rate guarantee by the government, reduces perceptions of the risk of borrowing in foreign currencies, and hence biases corporate borrowing towards foreign currency (Fisher (2001)). 
The rest of the paper is organized as follows. In Section 2, we explain the empirical methodology and definitions and the data sources of the key variables. In Section 3, we provide empirical evidence. In Section 4, we conclude and discuss directions for future research.

\section{Methodology and Data}

\subsection{Basic Specification}

We denote some measure of risk taking by firm $\mathrm{i}$ in country $\mathrm{k}$ at year $\mathrm{t}$ by $\mathrm{RT}_{\mathrm{ikt}}$. We will look at various proxies of corporate risk including corporate leverage ratio, cash holdings, risky investment and stock return volatility. The key empirical relationship that we examine relates one of the measures of corporate risk taking to the country-level ratio of foreign exchange reserves to GDP (denoted by $\mathrm{FXR}_{\mathrm{k}, \mathrm{t}-1}$ ), conditional on firm fixed effects (which encompass country fixed effects), year fixed effects, and other control variables. More specifically,

$$
\text { (1) } R T_{i k t}=\gamma F X R_{k, t-1}+\text { Controls }_{i k t}+\text { Firm_Fixed_Effects }+ \text { Year_Fixed_Effects }+e_{i k t}
$$

The set of control variables includes both firm-level variables such as size and growth opportunities, and country-level variables such as credit supply and capital account openness. Time-invariant country features such as legal origins, shareholder rights protection, creditor rights protection, and quality of the accounting system, and time-invariant firm features, such as sector affiliation, capital intensity, and political connections, are absorbed in the firm fixed effects. Time-varying common global shocks, such as the global interest rate, the global risk appetite, and the global demand shocks, are absorbed in the year fixed effects.

The standard errors of the coefficient estimates are clustered at the country-year level since the key regressor, $\operatorname{FXR}_{\mathrm{k}, \mathrm{t}-1}$, is at that level. The key parameter of interest is $\gamma$. In some specifications, we let $\gamma$ be a function of a firm's intrinsic dependence on external finance for either working capital or long-term investment expenditure. That is,

(2) $\gamma_{i}=\gamma_{0}+\gamma_{1}^{*}$ Dependence_on_external_finance ${ }_{i}$. 


\subsection{Key Data}

\subsubsection{Dependent variable - risk taking by firms}

We use a set of measures of corporate risk. The first one is financial leverage, i.e., the ratio of total debt over total asset, as in Claessens et al. (2001). Firms with higher leverage tend to face more risks when there is a liquidity shock to the economy. For example, Tong and Wei (2010) illustrate that firms with higher leverage suffered more during the 2008-09 global crisis.

The second one is corporate cash holding as in Coles, Daniel, Naveen (2006). Firms with smaller cash holdings tend to have a smaller cushion when faced with aggregate liquidity shocks. This proxy relates to risk-taking on firms' asset side, complementary to the first proxy of corporate risk, as leverage relates to firms' liability side. The two proxies can help addressing whether firms simply add debt when international capital is abundant or whether they also actively run down their own cash reserves.

The third measure is risky investment, as measured by relatively higher investment in R\&D and smaller investment in physical capital (see Coles, Daniel, Naveen (2006)). Risky investment may provide higher returns during normal times, but it can decrease firms' ability of getting financing during a crisis as firms will have relatively less collateral for borrowing. We proxy risky investment by $\log (1+\mathrm{RD} /$ Capital Expenditure $)$. This is because $\mathrm{R} \& \mathrm{D}$ are zeros for around $76 \%$ of firm-years. We take the log to reduce the impact of extreme values (firms that do not have any R\&D throughout our sample will be controlled for firm fixed effects).

The last measure is stock return volatility as measured by the log standard deviation of firms' weekly equity returns within the year (see Laeven and Levin (2009)). This dependent variable arguably captures the degree of business risk more directly. It is a market-based measure of firm risk, while the other three proxies are balance-sheet-based measures. In case there is some off-balance-sheet risk-taking of firms, such as hedging, stock return volatility can partially capture that. In robustness checks, we will further decompose total stock return volatility into market-wide volatility and idiosyncratic volatility by using a CAPM model. (The idiosyncratic stock return volatility is measured by the standard deviation of the residuals from the CAMP model within the firm-year). 


\subsubsection{Dependence on external finance}

We develop two measures of intrinsic dependence for external finance:

- Intrinsic dependence on external finance for investment (DEF_INV)

We construct a sector-level approximation of a firm's intrinsic demand on external finance for capital investment following a methodology in Rajan and Zingales (1998):

(4) Dependence on external finance for investment $=\frac{\text { capital expenditures }- \text { cash flow }}{\text { capital expenditures }}$,

where Cash flow $=$ cash flow from operations + decreases in inventories + decreases in receivables + increases in payables. All the numbers are based on U.S. firms, which are judged to be least likely to suffer from financing constraints (during a normal time) relative to firms in other countries. While the original Rajan and Zingales (1998) paper covers only 40 (mainly SIC 2-digit) sectors, we expand the coverage to around 250 SIC 3-digit sectors.

To calculate the demand for external financing of U.S. firms, we take the following steps. First, every firm in the COMPUSTA USA is sorted into one of the SIC 3-digit sectors. Second, we calculate the ratio of dependence on external finance for each firm from 19902006. Third, we calculate the sector-level median from firm ratios for each SIC 3-digit sector that contains at least 5 firms, and the median value is then chosen, to be the index of demand for external financing in that sector. Conceptually, the Rajan-Zingales (RZ) index aims to identify sector-level features, i.e. which sectors are naturally more dependent on external financing for their business operation. It ignores the question of which firms within a sector are more liquidity constrained. What the RZ index measures could be regarded as a "technical feature" of a sector, almost like a part of the production function. To capture the economic concept of the percentage of capital expenditure that has to be financed by external funding, we winsorize the RZ index to range between 0 and 1 .

- Intrinsic dependence on external finance for working capital (DEF_WK)

Besides capital needed for investment, working capital is required for a firm to operate and to satisfy both short-term debt payment and ongoing operational expenses. Firms may use lines of credit, term loans or commercial paper to cover such needs. Firms may also use trade credit (implicit borrowing from either upstream suppliers by delaying payments for 
inputs or from downstream customers by collecting payments before delivery of output) to finance the need for working capital. If a liquidity crunch makes it difficult for a firm to raise funds for working capital distinct from external financing for long-term investment, we would like to capture that. If there is an unexpected liquidity crunch for working capital, those industries that depend intrinsically more on external finance for working capital should experience a larger decline of stock prices.

We construct a sector-level measure of intrinsic need for external finance for working capital by "cash conversion cycle", which "is commonly used in financial analysis to measure the liquidity position of a firm" (Raddatz, 2006). The cycle measures the time elapsed from the moment a firm pays for its inputs to the moment it receives payment for the goods it sells. We assume that dependence on external finance for working capital is due to pure technological reasons, such as the length of time in the production process and the mode of operation. For U.S. firms during a non-crisis period, when the supply of finance is as abundant as in any country, the relative values of the cash conversion cycle across sectors reflect relative true needs for external finance for working capital. Specifically, ${ }^{3}$

Cash conversion cycle $=365 *\left(\frac{\text { inventories }- \text { account payables }}{\text { cost of goods sold }}+\frac{\text { account receivables }}{\text { total sales }}\right)$

It is used as a measure of dependence on external finance by Kroszner, Laeven, Klingebiel (2007) and Braun and Raddatz (2008) in addition to Raddatz (2006). We construct the index as follows: First, for each U.S. firm during 1990-2006, we calculate the cash conversion cycle based on the annual data from Compustat USA Industrial Annual. Second, we define the sector-level value of the index (for each SIC 3 digit sector) as the median across all firms in the sector. We assume the same index applies to all other countries. Across all 3-digit sectors, the median and mean values of the index are 87 and 89 days respectively, with a standard deviation of 29 days.

\subsubsection{Control variables}

We have the following macroeconomic variables related to the domestic and

\footnotetext{
${ }^{3}$ Inventories, accounts receivable, and accounts payable are year-end numbers, while costs of goods and sales are aggregated over the year. We multiply the ratio by 365 , i.e., the number of days in a year.
} 
international liquidity situation of a country. The domestic variables include domestic private credit over GDP and broad money over GDP. The international variables include international financial openness as measured by debt liability/GDP, as well as foreign assets plus liabilities over GDP, as in Milesi-Ferretti and Lane (2006).

We include traditional firm-level controls of leverage and closeness to default: firm growth opportunity (log of Tobin's Q), firm size (log of total assets), tangibility (property, plants and equipments over assets) and profitability (earnings before interest and tax/total asset). These variables have been applied before in Rajan and Zingales (1995) and others. We include firm fixed effects to control for time-invariant factors. We look at 5000 listed manufacturing firms in 24 emerging economies over the period from 2000 to 2006. Country coverage and summary statistics are provided in Tables $1 \mathrm{a}$ and $1 \mathrm{~b}$.

\section{Empirical Results}

\subsection{A First Look at the Data}

In Figure 3, we plot the average leverage ratio across firms in a country in a year against the reserve/GDP ratio in that country and that year for 24 emerging market economies during 2000-2006, conditional on country fixed effects and year fixed effects. From the 168 country-year observations, there is a clearly positive relationship between the two variables. The slope of the fitted line is 0.20 , with a standard error of 0.07 (and a tstatistic of 2.92).

Instead of taking the average across firms in a given country and year, one could filter the data differently. First, we pool all firm leverage ratios in all countries and years together, and take out country means and year fixed effects. Second, we classify all residuals into 20 quintiles based on the value of the RES/GDP ratios, with each quintile having $5 \%$ of the observations. Third, within each quintile, we compute the average leverage ratio. In Figure 4, we plot the average leverage ratio within a bin against the lower bound of the reserve/GDP ratio for that bin. Again, there is a clear positive slope in the graph. The slope is also about 0.20 . These two plots serve to illustrate that the positive correlation between country insurance and corporate leverage is not driven by one or two firms or by one or two countries.

In Figure 5, we plot a chart similar to Figure 4 but replace the leverage ratio with the cash/asset ratio. There we find a significantly negative slope in the graph. The slope 
coefficient is -0.06 and the standard error is 0.02 . That is, when reserve/GDP rises, firms hold smaller cash reserves relative to assets. In Figure 6, we replace Figure 5 with risky investment as the variable on the $y$-axis. A positive trend appears there: reserve accumulation is significantly associated with riskier investment. The slope is 0.084 and the standard error is 0.04. In Figure 7, we use firm-level stock return volatility as the variable on the y-axis. Again a positive correlation is found between reserve accumulation and stock return volatility. The slope coefficient is 1.04 and the standard error is 0.28 .

In the rest of the section, we will show that the positive correlation is robust to including other control variables, and reflects at least in part a causal effect of a change in a country's foreign exchange reserve on corporate risk taking.

\subsection{Firm Leverage and Country Insurance: How Robust is the Association?}

To examine the robustness of the association, we need to include macro variables to control for potential omitted variables and mechanical connections. For example, one channel through which a higher reserve/GDP may be associated with a higher corporate leverage is through capital inflows. In particular, capital inflows, if not sterilized fully by the central bank's interventions in the foreign exchange market, could translate into a more expansionary money supply, making credit cheaper and more easily available to firms. This, in turn, could induce firms to raise their leverage ratios. At the same time, capital inflows could directly add to a country's foreign reserve holdings (if they are not offset by other items in the balance of payments). In this scenario, it is not a higher reserve/GDP ratio that induces firms to raise their leverage ratios. Rather, it is unsterilized capital inflows that simultaneously expand the credit supply and raise the foreign reserve holdings.

Hence, we add a set of macroeconomic controls. The first one is broad money supply, i.e. M2/GDP ratio. We then add domestic credit/GDP ratio, which is a component of the high-powered money, but also a commonly used proxy for a country's level of financial development. Finally, we add two measures of a country's exposure to financial globalization: the ratio of the stock of foreign liabilities to GDP, and the ratio of the sum of foreign assets and foreign liabilities to GDP. They are meant to allow for the possibility that corporate leverage ratios are higher when access to the international capital market becomes easier. 
We further include firm-level control variables that the literature on international capital structure (e.g., Rajan and Zingales, 1995) deems important: firm growth opportunity ( $\log$ of Tobin's Q), profitability (earnings before interest and tax/total asset), firm size (log of total assets), and tangibility (property, plants and equipments over assets). We also include firm fixed effects - there are over 5000 of them. The firm fixed effects supersede both country fixed effects and sector fixed effects, since the latter two are linear combinations of firm fixed effects.

The regressions with the above control variables are presented in Table 2, where we estimate a series of proxies of corporate risk. The first dependent variable in Column 1 is the leverage ratio by firm and year. As explained earlier, the standard errors are clustered at the country-year level. The coefficient for reserve/GDP is 0.14 , with a $t$ statistic in excess of 3 . This reflects the fitted line represented in Figure 3. Corporations tend to have a higher leverage ratio in countries/years with a higher ratio of foreign reserve to GDP. An increase in the reserve/GDP ratio by one standard deviation (i.e., 0.048 conditional on country fixed effects) is associated with a higher leverage ratio by 0.7 percentage points. This is a nontrivial effect since the standard deviation of the leverage ratio in the sample is only 9.1 percentage points (conditional on firm fixed effects).

In Column 2, the dependent variable becomes cash holdings over assets. The ratio of reserve/GDP has a coefficient of -0.12 , significant at the $1 \%$ level. Based on this, if the ratio of reserve/GDP rises by one standard deviation (0.048), the cash holding as a share of assets will decrease by $0.6 \%(=0.048 * 0.12)$, which explains $9 \%$ of the standard deviation of the cash/asset ratio ( 0.064 when conditional on firm fixed effects).

In Column 3, the dependent variable is a proxy for risky investment. Here, a higher level of reserve is again significantly associated with a higher share of investment in risky projects. The coefficient is at 0.06 , significant at the $10 \%$ level. Hence if the ratio of reserve/GDP rises by one standard deviation (0.048), the share of risky investment will increase by $0.003\left(=0.048^{*} 0.06\right)$, which explains around $2.5 \%$ of the standard deviation of risky investment ( 0.115 conditional on firm fixed effects).

Finally, in Column 4, the stock return volatility is now the dependent variable. We find that the ratio of reserve/GDP is a significant predictor for stock return volatility. Based on the point estimate, if reserve/GDP goes up by one standard deviation (0.048), the stock 
return volatility will increase by $0.049\left(=0.048^{*} 1.03\right)$, which explains around $15 \%$ of the standard deviation of stock return volatility ( 0.33 when conditional on firm fixed effects).

Control variables have sensible signs. For example, firms with greater growth opportunities or that are more profitable have a lower leverage ratio. This is consistent with the idea that for these firms, the agency problem associated with free cash is less a problem. Larger firms and firms that have more tangible assets (which could be pledged as collaterals) have a higher leverage ratio, probably because it is relatively easy for them to borrow. Inclusion of these firm-level controls improves the fitness of the model. Interesting, it has no effect on the coefficient on the reserve/GDP ratio. Firms continue to have a higher leverage ratio if they are in a country/year that has a higher reserve/GDP ratio.

Note that macroeconomic controls could lead to an under-estimation of the coefficient on the Reserve/GDP ratio if part of the genuine effect of a higher reserve/GDP ratio on corporate risk is through increasing the money supply, as foreign reserve is a part of the high powered money after all. In any case, the coefficient on the reserve/GDP ratio in Table 2 is still statistically significant throughout the various proxies of corporate risks. Hence, we conclude that the positive relationship between corporate risk taking and countrylevel reserve/GDP ratio is robust to adding firm and macro features.

\subsection{Asymmetric Effects as a Function of Dependence on External Finance}

In this and the next two sub-sections, we explore three separate ways to investigate if the positive association between corporate risk and reserve holdings goes beyond a passive or a mechanical change in corporate risk taking due to capital inflows or a reverse causality.

We start by checking if the association is asymmetric depending on a sector's intrinsic dependence on external finance. Under the null that unsterilized capital inflows cause firms to passively increase their corporate risk, such as leverage ratios, we would expect approximately the same increase in the leverage ratios across all firms. In comparison, if firms actively adjust their leverage ratios in response to a higher reserve/GDP ratio, we would expect those firms that are intrinsically more dependent on external finance to adjust their leverage ratios more strongly since they were relatively more constrained in their external borrowing to begin with. 
In Column 1 of Table 3, we augment the regression by including an interaction term between reserve/GDP ratio and the index for dependence on external finance for working capital. (Note that the index for dependence on external finance itself does not change over time, and hence is absorbed by the firm fixed effects.) In this specification, the interaction term is positive (with the point estimate equal to 0.037 ) and statistically significant at the $1 \%$ level (with a t statistic of 3). In Column 1 of Table 3, we also incorporate an interaction term between an index for dependence on external finance for long-term investment and reserve/GDP ratio. The interaction term is positive (with a point estimate of 0.0033 ) but not significant. One interpretation is that in year-to-year changes in the reserve/GDP ratio, firms that are constrained by a working capital need respond by changing their leverage ratios more strongly and more visibly than firms that are constrained by a long-term investment need. Another interpretation is that the meaure of the dependence on external finance for long-term investment is noisier than the other index.

Based on the point estimate, with a DEP_WK of 3.7 (mean plus one standard deviation), one standard deviation rise of reserve/GDP will increase leverage by $4 \%$, explaining $20 \%$ of the standard deviation of leverage. On the contrary, for a DEP_WK of 1.7 (mean minus one standard deviation), one standard deviation rise of reserve/GDP will increase leverage by $2 \%$, only explaining $10 \%$ of the standard deviation of leverage.

In Column 2 of Table 3, we look at cash /assets as the dependent variable. There, the interaction term of reserve/GDP and DEP_WK is negative and significantly different from zero at the $1 \%$ level. That is, as reserves accumulate, firms that are more vulnerable to liquidity crisis (due to higher DEP_WK) actively reduce their cash cushion against liquidity shocks. In Column 3, we measure corporate risk by risky investment. We add the interaction terms between the reserves/GDP ratio and the two measures of dependence on external finance. Interestingly, both interaction terms are positive and significant at the $5 \%$ level. In Column 4, we measure corporate risk by stock return volatility. There, the interaction of reserves and DEP_INV is significantly positive at the 5\% level. The interaction of reserves and DEP_WK is also positive but less significant.

Taken together, the results in Table 3 imply that corporate risk taking tends to go up in countries/years in which the reserve/GDP ratio is higher. This effect is stronger for firms that have a higher intrinsic dependence on external finance. 


\subsection{Instrumental Variable Estimation}

The second approach to dealing with reverse causality and a mechanical correlation is to employ an instrumental variable approach.

By definition, foreign reserve holdings are the sum of three components: (a) cumulative net capital inflows (including foreign direct investment, foreign portfolio equity and debt, foreign bank loans, and trade credit), (b) cumulative remittances and transfers, and (c) cumulative trade surpluses in goods and services. In this subsection, we instrument reserves/GDP by trade surplus cumulative since 1999, normalized by the current-year GDP in U.S. dollars. The first-stage regression is presented in Table 4. The regressions include firm and year fixed effects, and cluster the standard errors at the country*year level. The coefficient on the cumulative trade surplus is positive (0.89) and significant at the $1 \%$ level.

The second stage results are presented in Table 5. We first examine the average effect on leverage in Column 1. The coefficient of reserves in the IV estimation (0.83) is six times that in the OLS regression (0.14). These findings suggest that a firm will respond to foreign reserves, but foreign reserves might be a noisy measure of country insurance, due to measurement errors. Hence, removing potential endogeneity and measurement errors actually strengthens the impact of the reserves on a firm's risk taking. Based on the IV estimate, an increase in the reserve/GDP ratio by one standard deviation (or 0.20) tends to lead to an increase in the leverage ratio by 16 percentage points $(0.83 * 0.20=0.16)$, which is economically significant (compared with the sample standard deviation of $20 \%$ for the leverage ratio across all firms in all years).

In Columns 2 to 4 of Table 5, we examine other proxies of corporate risk. Column 2 reports the estimation for cash holding over assets. The coefficient of instrumented reserve/GDP is -0.47 , significant at the $1 \%$ level. The coefficient in the IV estimation is about four times that in the OLS estimation.

Column 3 examines risky investment. There reserve/GDP is significant at the $10 \%$ level. The point estimate is about four times that in the OLS estimation, but the estimated standard errors in the IV estimation is also around four times that in the OLS estimation, then the significance level does not change much. In Column 4, we study stock return volatility. There the instrumented reserve/GDP turns out to be positive but insignificant. 
In Table 6, we examine the asymmetric impact of instrumented reserves/GDP as a function of a firm's intrinsic dependence on external finance for working capital and for capital expenditure, respectively (in specifications identical to those in Table 3). The interaction term between the instrumented reserves/GDP ratio and DEP_WK is significantly positive at the $1 \%$ level for leverage (Column 1). Moreover, the point estimate, 0.066 , almost doubles the corresponding OLS estimate (0.037 in Column 1 of Table 3). Again the IV estimation strengthens the economic magnitude of the reserves effect. Similar to the OLS estimation, the interaction term between the instrumented reserves/GDP ratio and DEP_INV is insignificant (but still positive).

In Column 2 of Table 6, we examine cash holdings as an alternative measure of corporate risk. There the interaction term of reserves and DEP_WK has a negative coefficient of -0.05 , which is significant at the $1 \%$ level. It is about the same as the OLS estimate. In Column 3 of Table 6 , we look at risky investment. We find the interaction of predicted reserves and DEP_INV to have a positive coefficient of 0.08 , is significant at the $1 \%$ level, and is $60 \%$ higher than the OLS estimate. In Column 4 , we use stock return volatility as a measure. There we find that the interaction term of reserves and DEP_WK is significant at $5 \%$, while the interaction term of reserves and DEP_INV is more significant at $1 \%$.

In the IV estimation, some might be concerned that trade surplus may have direct impact on a firm's risk taking. For example, more exports might cause firms to leverage up if firms choose debt over equity and internal cash to finance the expansion for exports. We have controlled for this channel by adding firm-level profits and growth opportunity. To more directly capture the impact of exports, we further include the exports at the 4-digit sector-level of a country as a control variable in both the first and second stages. The export data from year 1999 to 2006 is collected from the World Bank's World Integrated Trade Solution (WITS) dataset. We then take the one-year lag of $\log (1+$ exports) as a control variable, as some sectors in some countries have no exports. In the first stage, the log of sector-level exports has a positive coefficient of 0.002 and a standard error of 0.0024 , and hence it is not statistically significant. Trade surplus/GDP is still significant at the first stage, with a coefficient of 0.90 and a standard error of 0.30 . The second-stage results for instrumented reserve/GDP are presented in Table 7. Reassuringly, including sector-level exports does not change the results for reserve/GDP. The coefficient and significance levels 
of reserve/GDP in Table 7 are almost the same as those in Table 6 . Hence adding sector-level exports further supports trade surplus/GDP as a valid IV.

In Table 8, we further restrict our sample to manufacturing sectors whose median exports from 2000 to 2006 is below the country median over the same period. These sectors with low share of exports are less likely to be the main driver of country's trade surplus. Hence by focusing on low-exporting sectors, we aim to further strengthen the validity of trade surplus as an instrument variable. The regression results for these low-exporting sectors are comparable to the whole sample results in Table $7 .^{4}$ In Column 1 for leverage, the interaction of predicted reserves and DEP_WK is significantly positive, similar to Column 1 of Table 7. In Column 2 for cash holding, the interaction of reserves and DEP_RZ is significantly negative. In Column 3 for investment, the interaction of reserves and DEP_RZ is again significantly positive. Finally, in Column 4 for stock return volatility, the interaction of reserves and DEP_RZ is significantly positive as well.

As a robustness check, we have included other variables as additional controls into the first and second stages of estimation, such as the ratio of inward foreign direct investment over GDP, and the ratio of inward foreign portfolio investment over GDP. Reassuringly, including these variables does not change our key results with regard to reserve accumulation.

To summarize, to the extent that the IV strategy is valid, these results show that corporations tend to undertake actions that increase their risk taking in response to an increase in the reserves/GDP ratio. The pattern of the corporate responses is robust and is both economically and statistically significant.

\subsection{Additional Robustness Checks}

We further decompose total stock return volatility into systematic risk and idiosyncratic risk. Similar to Bartram, Brown and Stulz (2009), we estimate a separate CAPM model for each firm-year. Specifically,

$$
\text { Return }_{i, t}=a_{i, t}+b_{i, t} \text { MarketReturn }_{i, t}+\varepsilon_{i, t}
$$

\footnotetext{
${ }^{4}$ In the first stage estimation for Reserve/GDP, we also restrict the sample to the case where only low-exporting sectors are included.
} 
where Return $_{i, t}$ is the firm's weekly stock returns, MarketReturn ${ }_{i, t}$ is the return on the local market index in local currency, and $\varepsilon_{i, t}$ is an error term. The idiosyncratic risk is measured by the standard deviation of the residuals from the above CAPM model for each firm-year (i.e. $\sigma(\varepsilon)$ ). The systematic volatility is then measured as the square root of the difference between the total volatility $\left(\sigma^{2}\left(\operatorname{return}_{i t}\right)\right)$ and the idiosyncratic volatility $\left(\sigma^{2}(\varepsilon)\right)$.

According to Bartram et al (2009), idiosyncratic stock volatility can be affected by information environment (e.g. Morck, Yeung and Yu, 2000), and fundamental risk, with the later including investor protection, financial development and country risk. Moreover, "greater country risk, in the form of a higher threat of expropriation and/or macroeconomic volatility, makes firms riskier and decreases the rewards to risk-taking at the firm level. As a result, firms take fewer diversifiable risks." In the sense that reserves accumulation reduces macro risk, we would then likely observe an increase of firm's idiosyncratic risk-taking.

Table 9 reports how reserves affect market wide volatility and systematic volatility. The market-wide volatility is defined as the standard deviation of the country's stock market index within a year (we use the local currency MSCI market index). We start with the market-wide volatility in Column 1 . There we find a significantly negative coefficient for reserves. That is, consistent with the conventional wisdom, reserve accumulation indeed reduces the market-wide volatility. In Column 2, we then instrument reserves by cumulative trade surplus. There reserve accumulation reduces the market-wide volatility even more. In Column 3, we then examine the CAPM-model-based systematic volatility. There is no significant impact of reserves on systematic volatility on average. But reserve accumulation significantly reduces the systematic volatility for sectors with high liquidity needs of working capital (Column 4). If we instrument reserves by trade surplus (Columns 5 and 6), then results are similar to those in Columns 3 and 4.

The results for idiosyncratic stock return volatility are presented in Table 10. There, the results for foreign reserves are comparable with what we had earlier for the total stock return volatility. That is, reserve accumulation is still significantly associated with higher idiosyncratic risk (Column 1). Moreover, the interaction term of reserve and DEP_INV has a coefficient significantly higher than in the case for total return volatility. For example, the coefficient for Reserve*DEP_INV is 0.27 in the case for idiosyncratic return volatility 
(Column 4 of Table 10), while it is 0.17 in the case for total return volatility (Column 4 of Table 6). Hence, reserve accumulation has a larger impact on firms' idiosyncratic risks than on firms' total risks.

In our sample, China and India has more firms than other countries. One natural question is whether our results are based by these two countries. We deal with this issue in two ways. First, the conditional plots from Figures 4 to 7 suggest that the positive correlation between corporate risk taking and reserve accumulation is not driven by a particular country. Instead, the correlation is a general pattern across countries. Secondly, we drop China or India separately in regressions, and reassuringly, the results are still preserved.

\subsection{Further examining within-country heterogeneity}

The paper so far demonstrates that reserve accumulation increases risk taking. The underlying mechanism is that reserve accumulation reduces the macroeconomic risk such as currency crisis and liquidity risk, and hence firms take on more risk. There is a vast literature on early warning models that suggests that a higher level of FX reserves reduces the chance of a currency or a debt crisis. And Frenkel and Saravelos (2010) further find reserves as the most significant macroeconomic variable in reducing financial crisis. Hence it is reasonable to expect corporate managers to understand the linkage between reserves and crisis.

Note that while FX reserve might be used to help out with foreign currency debt of the private sector, our story does not have to involve bailout of banks or firms at all in principle. A higher level of FX reserve could directly reduce the risk of a sovereign debt crisis, and reduces the probability of and cushions the pain associated with a sudden reversal of international capital flows. Even without bailouts, this per se reduces the vulnerability of the banking sector and that of nonfinancial firms (if one could hold risk taking constant).

Nonetheless, there are some possibilities that the mechanism also works through the bailout channel. To explore this, we examine the following hypothesis: Domestically-owned firms may respond to reserve accumulation more than foreign-owned firms. The rationale is domestic firms may be more likely to be bailed out than foreign-owned firms due to political factors. To do this, we use the ownership data from OSIRIS dataset for the period covering 2005-06. The dataset covers the ultimate owner of a listed company. We look at the residentship of the largest shareholder and classify the firm as domestically owned if the 
largest shareholder and the firm come from the same country. We then create a dummy of one for domestically-owned firms. The percentage of domestic firm is $75.3 \%$ in our sample of manufacturing firms, vs $24.7 \%$ for that of foreign firms. We interact the dummy of domestic firm with Reserves/GDP, and we find that domestic firms engage in risk-taking more aggressively than non-domestic firms.

The results are presented in Table 11. There we have smaller sample than that in baseline Table 3, as some firms are not covered in the OSIRIS dataset. In Column 1 (leverage), reserve accumulation has no significant impact on foreign-owned firms, but it increases leverage of domestic firm statistically. Note that the differential impact is due to the magnitude of coefficients than to the standard errors. In Column 2 (cash), reserve accumulation reduces cash holding of domestic firms but has little impact on foreign-owned firms. Again, the difference is due to the coefficient magnitude than the standard errors. In Column 3 (investment), we find that domestic firms also respond more aggressively to reserve accumulation, although the difference is not significant. In Column 4 (stock return volatility), we find that reserve accumulation increases volatility significantly for domestic firms but not for foreign firms.

\subsection{Creditor rights and corporate risk-taking}

We use the creditor rights data from La Porta et al. (1998), with additional data for missing countries retrieved from Djankov et al (2007). The creditor rights index takes the value from 0 to 4 , with higher index associated with stronger creditor rights. Stronger creditor rights in default may induce firms to reduce ex-ante risk-taking to avoid insolvency, as strong creditor rights can penalize failing entrepreneurs and lead to inefficient liquidation that extinguishes the continuation option of the firm (see Acharya, Amihud, and Litov (2009)).

We hence include the interaction of creditor rights and Reserve/GDP in the set of explanatory variables. The results are presented in Table 12, with Columns 1-4 using reserve/GDP while Columns 5-8 using the predicted reserve/GDP from Table 4. In Table 12, we find that the impact of reserve on risk taking is significantly weaker in countries with stronger creditor rights. The interaction term of reserve and creditor rights is significantly negative for cash holding, suggesting that firms hold onto cash and take less risky financing 
policy when the creditor has stronger rights (Columns 2 and 6). We also find that the interaction term of reserve and creditor rights is significantly negative in the regression for stock return volatility as well (Columns 4 and 8).

\section{Concluding Remarks and Future Research}

If one holds private sector actions constant, an increase in a country's reserve/GDP ratio should enhance a country's ability to defend against macroeconomic risks associated with a sudden stop in international capital flows. This should imply a reduced vulnerability in the corporate sector to a negative shock that is external in origin. Yet, one cannot hold private sector actions constant. In particular, as a country improves its self-insurance in the form of a higher reserve/GDP ratio, moral hazard occurs in the form of corporations taking actions that could make themselves more vulnerable to a negative shock.

In this paper, we provide the first documentation in the literature of a robust pattern in the data, namely corporate risk-taking tends to be systematically higher in countries/years in which the reserve/GDP ratio is higher. We adopt several different approaches and conclude that at least a part of the strong, positive association reflects firms' undertaking actions that expose themselves to more risks when they see that their governments make progress in improving country-level self-insurance.

This may provide one explanation for an apparent puzzle during the 2008-2009 global economic crisis, namely that countries that had better self-insurance in the form of a higher reserve/GDP ratio, do not appear to experience less corporate difficulties during the crisis. This implies that when designing government policies, one has to take into account endogenous responses by the private sector. 


\section{References:}

1. Acharya, Viral V., Yakov Amihud, and Lubomir Litov (2009), "Creditor rights and corporate risk-taking".

2. Aizenman, Joshua and Jaewoo Lee, 2008. "Financial versus Monetary Mercantilism: Long-run View of Large International Reserves Hoarding," The World Economy, vol. 31(5), pages 593-611.

3. Bartram, Söhnke M., Gregory Brown, René M. Stulz, 2009, “Why Do Foreign Firms Have Less Idiosyncratic Risk than U.S. Firms?”, NBER Working Paper No. 14931.

4. Blanchard, Olivier, Faruqee, Hamid, and Klyuev, Vladimir, 2009. "Did Foreign Reserves Help Weather the Crisis", IMF Survey Magazine, IMF, October 8th. http:/www.imf.org/external/pubs/ft/survey/so/2009/num100809a.htm

5. Booth, L., Aivazian, A, Demirguc-Kunt, A., and V. Maksimovic, 2001, "Capital Structures in Developing Countries", Journal of Finance, , 87-130.

6. Claessens, Stijn, Djankov, Simeon and Nenova, Tatiana, 2000. "Corporate risk around the world," World Bank Policy Research Working Paper Series 2271.

7. Coles, Jeff, Daniel, Naveen and Naveen, Lalitha (2006), "Managerial incentives and risk-taking", Journal of Financial Economics 79:431-468.

8. Djankov, S., McLeish, C., Shleifer, A., 2007. Private credit in 129 countries. Journal of Financial Economics 84, 299-329.

9. Fisher, Stanley (2001), "Exchange rate regimes: is the bipolar view correct?" Journal of Economic Perspective, 15 (2), 3-24.

10. Frankel, Jeffrey and Rose, Andrew K., 1996. "Currency crashes in emerging markets: An empirical treatment," Journal of International Economics, vol. 41, pp. 351-366.

11. Frankel, Jeffrey and George Saravelos, 2010. "Are Leading Indicators of Financial Crises Useful for Assessing Country Vulnerability? Evidence from the 2008-09 Global Crisis," NBER Working Papers 16047.

12. Jeanne, Olivier \& Rancière, Romain, 2008. "The Optimal Level of International Reserves For Emerging Market Countries: A New Formula and Some Applications," CEPR Discussion Papers 6723, C.E.P.R. Discussion Papers.

13. John, Kose, Lubomir Litov, and Bernard Yeung, 2008, Corporate governance and risk-taking, Journal of Finance 63, 1679-1728. 
14. La Porta, R., Lopez-de-Silanes, F., Shleifer, A., Vishny, R., 1998. Law and finance. Journal of Political Economy 106, 1113-1155.

15. Kaminsky, Graciela and Carmen Reinhart (1999), "The Twin Crises: Causes of Banking and Balance-of-Payments Problems, American Economic Review, June 1999.

16. Laeven, Luc and Levine, Ross, 2009, "Bank governance, regulation and risk taking," Journal of Financial Economics vol. 93(2), pp. 259-275.

17. Li, Kai, Dale Griffin, Heng Yue, and Longkai Zhao, 2010, "Cultural Values and Corporate Risk-Taking", University of British Columbia Working Paper.

18. Morck, Randall, Bernard Yeung, and Wayne Yu, 2000, "The information content of stock markets: Why do emerging markets have synchronous stock price movements?" Journal of Financial Economics 58, 215-260.

19. Obstfeld, Maurice, 1994. "Risk-Taking, Global Diversification, and Growth," American Economic Review, American Economic Association, vol. 84(5), pp. 1310-29.

20. Obstfeld, Maurice and Jay C. Shambaugh and Alan M. Taylor, 2009, "Financial Instability, Reserves, and Central Bank Swap Lines in the Panic of 2008," American Economic Review, vol. 99(2), pages 480-86.

21. Raddatz, Claudio, 2006, "Liquidity needs and vulnerability to financial underdevelopment," Journal of Financial Economics, vol. 80(3), pp. 677-722.

22. Rajan, Raghuram and Luigi Zingales, 1995, "What Do We Know About Capital Structure? Some Evidence from International Data." Journal of Finance 50(5), pp. 1421-60.

23. Rajan, Raghuram and Luigi Zingales, 1998, "Financial dependence and growth," American Economic Review, vol. 88(3), pp. 559-586.

24. Tong, Hui and Shang-Jin Wei, 2010. "The Composition Matters: Capital Inflows and Liquidity Crunch during a Global Economic Crisis," Review of Financial Studies, forthcoming. 
Table 1. Summary Statistics

\begin{tabular}{lllllll}
\hline Variables & Obs & Median & Mean & St Dev & Min & Max \\
& & & & & & \\
Leverage & 24617 & 0.24 & 0.26 & 0.20 & 0.00 & 1.00 \\
cash/assets & 24617 & 0.08 & 0.13 & 0.13 & 0.00 & 1.00 \\
Risky Investment & 23819 & 0.00 & 0.07 & 0.24 & 0.00 & 1.76 \\
Stock Return Volatility & 23221 & -0.84 & -0.83 & 0.50 & -2.24 & 0.57 \\
Growth Opportunity & 24605 & 0.85 & 1.11 & 0.91 & 0.18 & 7.62 \\
Firm size & 24617 & 9.59 & 10.08 & 2.86 & -0.13 & 20.37 \\
Profit/asset & 24388 & 0.07 & 0.06 & 0.13 & -0.66 & 0.41 \\
Tangibility & 24603 & 0.38 & 0.38 & 0.19 & 0.00 & 0.90 \\
Reserves/GDP & 168 & 0.16 & 0.22 & 0.2 & 0.02 & 1.03 \\
M2/GDP & 168 & 51.57 & 67.37 & 47.94 & 16.86 & 256.63 \\
Domestic Credit/GDP & 168 & 34.92 & 60.75 & 45.84 & 10.49 & 189.86 \\
External debt/GDP & 168 & 0.42 & 0.54 & 0.43 & 0.12 & 2.18 \\
Financial Openness & 168 & 1.26 & 2.01 & 2.74 & 0.41 & 14.35 \\
Cumulative Trade Surplus/GDP & 168 & 0.00 & 0.01 & 0.03 & -0.07 & 0.13 \\
DEP_WK & 117 & 2.62 & 2.71 & 0.99 & 0.64 & 4.54 \\
DEP_INV & 111 & 0.00 & 0.67 & 1.00 & 0.00 & 3.44 \\
\hline
\end{tabular}




\begin{tabular}{ll}
\hline \multicolumn{1}{c}{ Table $1 \boldsymbol{l b}$ : List of Countries } \\
\hline Country & Number of firms \\
& \\
Argentina & 35 \\
Brazil & 155 \\
Chile & 60 \\
China & 939 \\
Colombia & 17 \\
Czech Republic & 21 \\
Egypt & 32 \\
Hong Kong & 377 \\
Hungary & 18 \\
India & 1,214 \\
Indonesia & 141 \\
Israel & 80 \\
Korea (South) & 723 \\
Malaysia & 481 \\
Mexico & 53 \\
Pakistan & 97 \\
Peru & 27 \\
Philippines & 42 \\
Poland & 98 \\
Russian Federation & 32 \\
Singapore & 294 \\
South Africa & 115 \\
Thailand & 243 \\
Turkey & 137 \\
Total & 5,431 \\
\hline
\end{tabular}


Table 2. The Effect of Reserves on Risk Taking

\begin{tabular}{|c|c|c|c|c|}
\hline & Leverage & Cash/Assets & $\begin{array}{l}\text { Risky } \\
\text { Investment }\end{array}$ & $\begin{array}{l}\text { Stock Return } \\
\text { Volatility }\end{array}$ \\
\hline Reserve/GDP & $\begin{array}{l}0.14 * * * \\
{[0.045]}\end{array}$ & $\begin{array}{l}-0.12 * * * \\
{[0.027]}\end{array}$ & $\begin{array}{l}0.059 * \\
{[0.031]}\end{array}$ & $\begin{array}{l}1.03 * * \\
{[0.42]}\end{array}$ \\
\hline Growth opportunity & $\begin{array}{l}0.0034 \\
{[0.0030]}\end{array}$ & $\begin{array}{l}0.013 * * * \\
{[0.0014]}\end{array}$ & $\begin{array}{l}-0.0013 \\
{[0.0032]}\end{array}$ & $\begin{array}{l}0.011 \\
{[0.014]}\end{array}$ \\
\hline Firm size & $\begin{array}{l}0.055 * * * \\
{[0.0050]}\end{array}$ & $\begin{array}{l}-0.0024 \\
{[0.0035]}\end{array}$ & $\begin{array}{l}-0.017 * * * \\
{[0.0052]}\end{array}$ & $\begin{array}{l}-0.095 * * * \\
{[0.011]}\end{array}$ \\
\hline Profit & $\begin{array}{l}-0.26 * * * \\
{[0.018]}\end{array}$ & $\begin{array}{l}0.063 * * * \\
{[0.0076]}\end{array}$ & $\begin{array}{l}-0.098 * * * \\
{[0.021]}\end{array}$ & $\begin{array}{l}-0.097 * * \\
{[0.044]}\end{array}$ \\
\hline Tangibility & $\begin{array}{l}0.17 * * * \\
{[0.018]}\end{array}$ & $\begin{array}{l}-0.31 * * * \\
{[0.014]}\end{array}$ & $\begin{array}{l}-0.086^{* * *} \\
{[0.019]}\end{array}$ & $\begin{array}{l}0.064 * \\
{[0.037]}\end{array}$ \\
\hline M2/GDP & $\begin{array}{l}0.0011 * * * \\
{[0.00030]}\end{array}$ & $\begin{array}{l}0.00038 * \\
{[0.00020]}\end{array}$ & $\begin{array}{l}0.00046^{*} \\
{[0.00028]}\end{array}$ & $\begin{array}{l}0.0033 \\
{[0.0025]}\end{array}$ \\
\hline Domestic Credit/GDP & $\begin{array}{l}-0.00068 * * * \\
{[0.00020]}\end{array}$ & $\begin{array}{l}-0.00016 \\
{[0.00010]}\end{array}$ & $\begin{array}{l}0.00047 * * \\
{[0.00019]}\end{array}$ & $\begin{array}{l}-0.00052 \\
{[0.0016]}\end{array}$ \\
\hline Foreign Debt/GDP & $\begin{array}{l}0.067 * * * \\
{[0.020]}\end{array}$ & $\begin{array}{l}0.029 * * \\
{[0.013]}\end{array}$ & $\begin{array}{l}0.0093 \\
{[0.017]}\end{array}$ & $\begin{array}{l}0.49 * * * \\
{[0.16]}\end{array}$ \\
\hline Financial Openness & $\begin{array}{l}-0.014 * * \\
{[0.0055]}\end{array}$ & $\begin{array}{l}-0.0095 * * * \\
{[0.0031]}\end{array}$ & $\begin{array}{l}-0.0056 \\
{[0.0045]}\end{array}$ & $\begin{array}{l}-0.13 * * * \\
{[0.042]}\end{array}$ \\
\hline Firm and year fixed effects & yes & yes & yes & yes \\
\hline Observations & 24386 & 24364 & 23623 & 23007 \\
\hline R-squared & 0.137 & 0.152 & 0.019 & 0.137 \\
\hline Number of firms & 5410 & 5406 & 5355 & 4696 \\
\hline
\end{tabular}

, the standard errors are clustered at the country-year level. 
Table 3. Asymmetric Impact of Reserves on Risk Taking

\begin{tabular}{lllll}
\hline & Leverage & Cash/Assets & $\begin{array}{l}\text { Risky } \\
\text { Investment }\end{array}$ & $\begin{array}{l}\text { Stock return } \\
\text { Volatility }\end{array}$ \\
& & & & \\
Reserve/GDP & 0.043 & 0.0068 & $-0.087^{*}$ & 0.63 \\
& {$[0.060]$} & {$[0.025]$} & {$[0.051]$} & {$[0.51]$} \\
Reserve/GDP*DEP_WK & $0.037^{* * *}$ & $-0.045^{* * *}$ & $0.043^{* *}$ & 0.098 \\
& {$[0.013]$} & {$[0.011]$} & {$[0.019]$} & {$[0.065]$} \\
Reserve/GDP*DEP_INV & 0.0033 & -0.0098 & $0.052^{* *}$ & $0.14^{* * *}$ \\
& {$[0.010]$} & {$[0.0095]$} & {$[0.020]$} & {$[0.048]$} \\
Growth opportunity & 0.0025 & $0.013^{* * *}$ & -0.0013 & 0.012 \\
& {$[0.0029]$} & {$[0.0015]$} & {$[0.0033]$} & {$[0.013]$} \\
Firm size & $0.055^{* * *}$ & -0.0035 & $-0.018^{* * *}$ & $-0.092^{* * *}$ \\
& {$[0.0052]$} & {$[0.0035]$} & {$[0.0057]$} & {$[0.011]$} \\
Profit & $-0.26^{* * *}$ & $0.064^{* * *}$ & $-0.10^{* * *}$ & $-0.10^{* *}$ \\
Tangibility & {$[0.018]$} & {$[0.0080]$} & {$[0.022]$} & {$[0.042]$} \\
& $0.17^{* * *}$ & $-0.32^{* * *}$ & $-0.090^{* * *}$ & $0.078^{* *}$ \\
M2/GDP & {$[0.018]$} & {$[0.014]$} & {$[0.020]$} & {$[0.035]$} \\
& $0.0010^{* * *}$ & $0.00037^{*}$ & 0.00041 & 0.0034 \\
Domestic Credit/GDP & {$[0.00030]$} & {$[0.00021]$} & {$[0.00029]$} & {$[0.0025]$} \\
& $-0.00065^{* * *}$ & -0.000088 & $0.00047^{* *}$ & -0.0005 \\
Foreign Debt/GDP & {$[0.00020]$} & {$[0.000098]$} & {$[0.00019]$} & {$[0.0016]$} \\
& $0.065^{* * *}$ & $0.025^{* *}$ & 0.0042 & $0.52^{* * *}$ \\
Financial Openness & {$[0.021]$} & {$[0.013]$} & {$[0.018]$} & {$[0.16]$} \\
& $-0.012^{* *}$ & $-0.0086^{* * *}$ & -0.0051 & $-0.14^{* * *}$ \\
firm and year dummies & {$[0.0056]$} & {$[0.0032]$} & {$[0.0047]$} & {$[0.042]$} \\
Observations & $\mathrm{y}$ & $\mathrm{y}$ & $\mathrm{y}$ & $\mathrm{y}$ \\
R-squared & 22620 & 22600 & 21945 & 21448 \\
Number of firms & 0.137 & 0.154 & 0.02 & 0.143 \\
\hline
\end{tabular}




\begin{tabular}{ll}
\hline \multicolumn{1}{c}{ Table 4. First-stage Estimation of Reserves } \\
\hline Cumulative Trade Surplus/GDP & $0.89^{* * *}$ \\
Growth opportunity & {$[0.30]$} \\
& $-0.0031^{* *}$ \\
Firm size & {$[0.0013]$} \\
& -0.0024 \\
Profit & {$[0.0019]$} \\
& 0.0023 \\
Tangibility & {$[0.0043]$} \\
& 0.009 \\
M2/GDP & {$[0.0059]$} \\
& $0.0049^{* * *}$ \\
Domestic Credit/GDP & {$[0.00083]$} \\
& $-0.0016^{* * *}$ \\
Foreign Debt Stock/GDP & {$[0.00058]$} \\
& $0.14^{* * *}$ \\
Financial Openness & {$[0.044]$} \\
& $-0.043^{* * *}$ \\
Observations & {$[0.013]$} \\
Number of firm & 24386 \\
R-squared & 5410 \\
Firm and year fixed effects & 0.712 \\
\hline
\end{tabular}


Table 5. The Effect of Reserves on Risk Taking-IV

\begin{tabular}{|c|c|c|c|c|}
\hline & Leverage & Cash/Assets & $\begin{array}{l}\text { Risky } \\
\text { Investment }\end{array}$ & $\begin{array}{l}\text { Stock Return } \\
\text { Volatility }\end{array}$ \\
\hline Predicted Reserves & $\begin{array}{l}0.83 * * * \\
{[0.18]}\end{array}$ & $\begin{array}{l}-0.47 * * * \\
{[0.086]}\end{array}$ & $\begin{array}{l}0.24 * \\
{[0.13]}\end{array}$ & $\begin{array}{l}0.95 \\
{[1.22]}\end{array}$ \\
\hline Growth opportunity & $\begin{array}{l}0.0068 * * \\
{[0.0028]}\end{array}$ & $\begin{array}{l}0.011 * * * \\
{[0.0014]}\end{array}$ & $\begin{array}{l}-0.00041 \\
{[0.0032]}\end{array}$ & $\begin{array}{l}0.01 \\
{[0.014]}\end{array}$ \\
\hline Firm size & $\begin{array}{l}0.058 * * * \\
{[0.0050]}\end{array}$ & $\begin{array}{l}-0.0036 \\
{[0.0034]}\end{array}$ & $\begin{array}{l}-0.016 * * * \\
{[0.0052]}\end{array}$ & $\begin{array}{l}-0.096 * * * \\
{[0.011]}\end{array}$ \\
\hline Profit & $\begin{array}{l}-0.26 * * * \\
{[0.018]}\end{array}$ & $\begin{array}{l}0.063 * * * \\
{[0.0076]}\end{array}$ & $\begin{array}{l}-0.098 * * * \\
{[0.021]}\end{array}$ & $\begin{array}{l}-0.096 * * \\
{[0.044]}\end{array}$ \\
\hline Tangibility & $\begin{array}{l}0.17 * * * \\
{[0.018]}\end{array}$ & $\begin{array}{l}-0.31 * * * \\
{[0.014]}\end{array}$ & $\begin{array}{l}-0.087 * * * \\
{[0.019]}\end{array}$ & $\begin{array}{l}0.065 \\
{[0.039]}\end{array}$ \\
\hline $\mathrm{M} 2 / \mathrm{GDP}$ & $\begin{array}{l}-0.0017 * * * \\
{[0.00061]}\end{array}$ & $\begin{array}{l}0.0018 * * * \\
{[0.00036]}\end{array}$ & $\begin{array}{l}-0.00027 \\
{[0.00049]}\end{array}$ & $\begin{array}{l}0.0037 \\
{[0.0049]}\end{array}$ \\
\hline Domestic Credit/GDP & $\begin{array}{l}0.00087^{*} \\
{[0.00047]}\end{array}$ & $\begin{array}{l}-0.00094 * * * \\
{[0.00022]}\end{array}$ & $\begin{array}{l}0.00087 * * * \\
{[0.00032]}\end{array}$ & $\begin{array}{l}-0.0007 \\
{[0.0032]}\end{array}$ \\
\hline Foreign Debt/GDP & $\begin{array}{l}-0.043 \\
{[0.030]}\end{array}$ & $\begin{array}{l}0.084 * * * \\
{[0.019]}\end{array}$ & $\begin{array}{l}-0.02 \\
{[0.025]}\end{array}$ & $\begin{array}{l}0.50 * * \\
{[0.22]}\end{array}$ \\
\hline Financial Openness & $\begin{array}{l}0.016 * * \\
{[0.0073]}\end{array}$ & $\begin{array}{l}-0.025 * * * \\
{[0.0046]}\end{array}$ & $\begin{array}{l}0.0022 \\
{[0.0062]}\end{array}$ & $\begin{array}{l}-0.14 * * \\
{[0.059]}\end{array}$ \\
\hline Firm and year dummies & yes & yes & yes & yes \\
\hline Observations & 24386 & 24364 & 23623 & 23007 \\
\hline R-squared & 0.14 & 0.152 & 0.019 & 0.13 \\
\hline Number of firms & 5410 & 5406 & 5355 & 4696 \\
\hline
\end{tabular}


Table 6. Asymmetric Impact of Reserves on Corporate Risk-Taking--IV Estimation

\begin{tabular}{|c|c|c|c|c|}
\hline VARIABLES & Leverage & Cash/Assets & $\begin{array}{l}\text { Risky } \\
\text { Investment }\end{array}$ & $\begin{array}{l}\text { Stock Return } \\
\text { Volatility }\end{array}$ \\
\hline Predicted Reserves & $\begin{array}{l}0.63 * * * \\
{[0.20]}\end{array}$ & $\begin{array}{l}-0.33 * * * \\
{[0.081]}\end{array}$ & $\begin{array}{l}0.15 \\
{[0.15]}\end{array}$ & $\begin{array}{l}0.23 \\
{[1.19]}\end{array}$ \\
\hline Predicted Reserves*DEP_WK & $\begin{array}{l}0.066 * * * \\
{[0.020]}\end{array}$ & $\begin{array}{l}-0.050 * * * \\
{[0.013]}\end{array}$ & $\begin{array}{l}0.023 \\
{[0.028]}\end{array}$ & $\begin{array}{l}0.14 * * \\
{[0.069]}\end{array}$ \\
\hline Predicted Reserves*DEP_INV & $\begin{array}{l}0.0087 \\
{[0.014]}\end{array}$ & $\begin{array}{l}-0.017 \\
{[0.012]}\end{array}$ & $\begin{array}{l}0.079 * * * \\
{[0.026]}\end{array}$ & $\begin{array}{l}0.17 * * * \\
{[0.047]}\end{array}$ \\
\hline Growth opportunity & $\begin{array}{l}0.0058 * * \\
{[0.0027]}\end{array}$ & $\begin{array}{l}0.011 * * * \\
{[0.0014]}\end{array}$ & $\begin{array}{l}-0.00025 \\
{[0.0034]}\end{array}$ & $\begin{array}{l}0.011 \\
{[0.014]}\end{array}$ \\
\hline Firm size & $\begin{array}{l}0.058 * * * \\
{[0.0053]}\end{array}$ & $\begin{array}{l}-0.0046 \\
{[0.0034]}\end{array}$ & $\begin{array}{l}-0.017 * * * \\
{[0.0057]}\end{array}$ & $\begin{array}{l}-0.094 * * * \\
{[0.011]}\end{array}$ \\
\hline Profit & $\begin{array}{l}-0.26 * * * \\
{[0.017]}\end{array}$ & $\begin{array}{l}0.064 * * * \\
{[0.0080]}\end{array}$ & $\begin{array}{l}-0.10 * * * \\
{[0.022]}\end{array}$ & $\begin{array}{l}-0.10 * * \\
{[0.042]}\end{array}$ \\
\hline Tangibility & $\begin{array}{l}0.17 * * * \\
{[0.018]}\end{array}$ & $\begin{array}{l}-0.32 * * * \\
{[0.014]}\end{array}$ & $\begin{array}{l}-0.092 * * * \\
{[0.020]}\end{array}$ & $\begin{array}{l}0.081 * * \\
{[0.037]}\end{array}$ \\
\hline M2/GDP & $\begin{array}{l}-0.0017 * * * \\
{[0.00058]}\end{array}$ & $\begin{array}{l}0.0018 * * * \\
{[0.00034]}\end{array}$ & $\begin{array}{l}-0.00043 \\
{[0.00051]}\end{array}$ & $\begin{array}{l}0.0045 \\
{[0.0047]}\end{array}$ \\
\hline Domestic Credit/GDP & $\begin{array}{l}0.00085^{*} \\
{[0.00045]}\end{array}$ & $\begin{array}{l}-0.00088 * * * \\
{[0.00021]}\end{array}$ & $\begin{array}{l}0.00092 * * * \\
{[0.00033]}\end{array}$ & $\begin{array}{l}-0.0011 \\
{[0.0031]}\end{array}$ \\
\hline Foreign Debt/GDP & $\begin{array}{l}-0.041 \\
{[0.029]}\end{array}$ & $\begin{array}{l}0.082 * * * \\
{[0.017]}\end{array}$ & $\begin{array}{l}-0.028 \\
{[0.026]}\end{array}$ & $\begin{array}{l}0.57 * * * \\
{[0.21]}\end{array}$ \\
\hline Financial Openness & $\begin{array}{l}0.016 * * \\
{[0.0071]}\end{array}$ & $\begin{array}{l}-0.024 * * * \\
{[0.0043]}\end{array}$ & $\begin{array}{l}0.0035 \\
{[0.0064]}\end{array}$ & $\begin{array}{l}-0.15 * * * \\
{[0.057]}\end{array}$ \\
\hline Firm and year fixed effects & yes & yes & yes & yes \\
\hline Observations & 22620 & 22600 & 21945 & 21448 \\
\hline R-squared & 0.141 & 0.155 & 0.021 & 0.137 \\
\hline Number of firms & 4974 & 4970 & 4926 & 4374 \\
\hline
\end{tabular}




\section{Table 7. Asymmetric Impact of Reserves on Corporate Risk-Taking --IV Estimation with Sector-level Exports}

\begin{tabular}{|c|c|c|c|c|}
\hline & Leverage & Cash/Assets & $\begin{array}{l}\text { Risky } \\
\text { Investment }\end{array}$ & $\begin{array}{l}\text { Stock Return } \\
\text { Volatility }\end{array}$ \\
\hline Predicted Reserves & $\begin{array}{l}0.61 * * * \\
{[0.20]}\end{array}$ & $\begin{array}{l}-0.31 * * * \\
{[0.079]}\end{array}$ & $\begin{array}{l}0.14 \\
{[0.14]}\end{array}$ & $\begin{array}{l}0.26 \\
{[1.17]}\end{array}$ \\
\hline Predicted Reserves*DEP_WK & $\begin{array}{l}0.066 * * * \\
{[0.020]}\end{array}$ & $\begin{array}{l}-0.049 * * * \\
{[0.013]}\end{array}$ & $\begin{array}{l}0.024 \\
{[0.028]}\end{array}$ & $\begin{array}{l}0.14 * * \\
{[0.069]}\end{array}$ \\
\hline Predicted Reserves*DEP_INV & $\begin{array}{l}0.0095 \\
{[0.014]}\end{array}$ & $\begin{array}{l}-0.017 \\
{[0.012]}\end{array}$ & $\begin{array}{l}0.079 * * * \\
{[0.026]}\end{array}$ & $\begin{array}{l}0.17 * * * \\
{[0.047]}\end{array}$ \\
\hline Growth opportunity & $\begin{array}{l}0.0058 * * \\
{[0.0027]}\end{array}$ & $\begin{array}{l}0.011 * * * \\
{[0.0014]}\end{array}$ & $\begin{array}{l}-0.00024 \\
{[0.0034]}\end{array}$ & $\begin{array}{l}0.011 \\
{[0.014]}\end{array}$ \\
\hline Firm size & $\begin{array}{l}0.058 * * * \\
{[0.0053]}\end{array}$ & $\begin{array}{l}-0.005 \\
{[0.0034]}\end{array}$ & $\begin{array}{l}-0.017 * * * \\
{[0.0057]}\end{array}$ & $\begin{array}{l}-0.094 * * * \\
{[0.011]}\end{array}$ \\
\hline Profit & $\begin{array}{l}-0.26 * * * \\
{[0.017]}\end{array}$ & $\begin{array}{l}0.064 * * * \\
{[0.0080]}\end{array}$ & $\begin{array}{l}-0.10^{* * * *} \\
{[0.022]}\end{array}$ & $\begin{array}{l}-0.10 * * \\
{[0.042]}\end{array}$ \\
\hline Tangibility & $\begin{array}{l}0.17 * * * \\
{[0.018]}\end{array}$ & $\begin{array}{l}-0.32 * * * \\
{[0.014]}\end{array}$ & $\begin{array}{l}-0.092 * * * \\
{[0.020]}\end{array}$ & $\begin{array}{l}0.081 * * \\
{[0.037]}\end{array}$ \\
\hline Log of sector-level exports & $\begin{array}{l}-0.0028 * * * \\
{[0.00085]}\end{array}$ & $\begin{array}{l}0.0030 * * * \\
{[0.00077]}\end{array}$ & $\begin{array}{l}-0.00041 \\
{[0.00092]}\end{array}$ & $\begin{array}{l}0.0069 \\
{[0.0083]}\end{array}$ \\
\hline $\mathrm{M} 2 / \mathrm{GDP}$ & $\begin{array}{l}-0.0016 * * * \\
{[0.00057]}\end{array}$ & $\begin{array}{l}0.0017 * * * \\
{[0.00033]}\end{array}$ & $\begin{array}{l}-0.00042 \\
{[0.00050]}\end{array}$ & $\begin{array}{l}0.0044 \\
{[0.0046]}\end{array}$ \\
\hline Domestic Credit/GDP & $\begin{array}{l}0.00083 * \\
{[0.00045]}\end{array}$ & $\begin{array}{l}-0.00087 * * * \\
{[0.00021]}\end{array}$ & $\begin{array}{l}0.00092 * * * \\
{[0.00033]}\end{array}$ & $\begin{array}{l}-0.0011 \\
{[0.0030]}\end{array}$ \\
\hline Foreign Debt/GDP & $\begin{array}{l}-0.036 \\
{[0.029]}\end{array}$ & $\begin{array}{l}0.076 * * * \\
{[0.017]}\end{array}$ & $\begin{array}{l}-0.027 \\
{[0.026]}\end{array}$ & $\begin{array}{l}0.56 * * * \\
{[0.21]}\end{array}$ \\
\hline Financial Openness & $\begin{array}{l}0.014 * * \\
{[0.0069]}\end{array}$ & $\begin{array}{l}-0.022 * * * \\
{[0.0043]}\end{array}$ & $\begin{array}{l}0.0032 \\
{[0.0063]}\end{array}$ & $\begin{array}{l}-0.15^{* * *} \\
{[0.056]}\end{array}$ \\
\hline Observations & 22620 & 22600 & 21945 & 21448 \\
\hline R-squared & 0.141 & 0.156 & 0.021 & 0.137 \\
\hline Number of firms & 4974 & 4970 & 4926 & 4374 \\
\hline
\end{tabular}


Table 8. Asymmetric Impact of Reserves on Corporate Risk-Taking --IV Estimation with Low Exporting Sectors

\begin{tabular}{lllll}
\hline & Leverage & Cash/Asset & $\begin{array}{l}\text { Risky } \\
\text { Investment }\end{array}$ & $\begin{array}{l}\text { Stock Return } \\
\text { Volatility }\end{array}$ \\
& & & & \\
Predicted Reserves & $0.67^{* * *}$ & $-0.29^{* *}$ & -0.15 & 1.01 \\
& {$[0.18]$} & {$[0.11]$} & {$[0.16]$} & {$[1.15]$} \\
Predicted Reserves*DEP_WK & $0.077^{* * *}$ & -0.012 & 0.04 & 0.053 \\
& {$[0.024]$} & {$[0.017]$} & {$[0.029]$} & {$[0.075]$} \\
Predicted Reserves*DEP_INV & -0.0092 & $-0.047^{* * *}$ & $0.071^{*}$ & $0.43^{* * *}$ \\
& {$[0.025]$} & {$[0.015]$} & {$[0.039]$} & {$[0.082]$} \\
Growth opportunity & 0.0033 & $0.014^{* * *}$ & 0.0031 & $0.029^{*}$ \\
& {$[0.0032]$} & {$[0.0018]$} & {$[0.0038]$} & {$[0.015]$} \\
Firm size & $0.046^{* * *}$ & $-0.0092^{*}$ & $-0.014^{* *}$ & $-0.098^{* * *}$ \\
& {$[0.0058]$} & {$[0.0051]$} & {$[0.0057]$} & {$[0.015]$} \\
Profit & $-0.23^{* * *}$ & $0.039^{* * *}$ & $-0.076^{* * *}$ & $-0.097^{*}$ \\
Tangibility & {$[0.021]$} & {$[0.0099]$} & {$[0.022]$} & {$[0.055]$} \\
& $0.15^{* * *}$ & $-0.33^{* * *}$ & $-0.065^{* * *}$ & $0.17 * * *$ \\
M2/GDP & {$[0.023]$} & {$[0.019]$} & {$[0.023]$} & {$[0.055]$} \\
& $-0.0024^{* * *}$ & $0.0016^{* * *}$ & 0.00074 & 0.0011 \\
Domestic Credit/GDP & {$[0.00058]$} & {$[0.00057]$} & {$[0.00064]$} & {$[0.0048]$} \\
& $0.00098^{* *}$ & $-0.00065^{* *}$ & 0.00008 & -0.00019 \\
Foreign Debt/GDP & {$[0.00043]$} & {$[0.00030]$} & {$[0.00033]$} & {$[0.0031]$} \\
& -0.044 & $0.076^{* * *}$ & 0.025 & $0.48^{* *}$ \\
Financial Openness & {$[0.030]$} & {$[0.023]$} & {$[0.029]$} & {$[0.21]$} \\
Log of sector-level exports & $0.023^{* * *}$ & $-0.024^{* * *}$ & -0.011 & $-0.12^{* *}$ \\
& {$[0.0071]$} & {$[0.0064]$} & {$[0.0076]$} & {$[0.056]$} \\
Observations & -0.0021 & 0.0017 & 0.0014 & 0.0049 \\
R-squared & {$[0.0023]$} & {$[0.0022]$} & {$[0.0036]$} & {$[0.013]$} \\
Number of firms & 10892 & 10879 & 10546 & 10336 \\
\hline & 0.131 & 0.166 & 0.016 & 0.15 \\
& 2379 & 2375 & 2354 & 2081 \\
\hline
\end{tabular}


Table 9. The Impact of Reserves on Market-wide and Systematic Stock Return Volatility

\begin{tabular}{|c|c|c|c|c|c|c|}
\hline & $\begin{array}{l}\text { Market- } \\
\text { wide }\end{array}$ & $\begin{array}{l}\text { Market- } \\
\text { wide-IV }\end{array}$ & $\begin{array}{l}\text { Systematic- } \\
\text { firm }\end{array}$ & $\begin{array}{l}\text { Systematic- } \\
\text { firm }\end{array}$ & $\begin{array}{l}\text { Systematic- } \\
\text { firm-IV }\end{array}$ & $\begin{array}{l}\text { Systematic- } \\
\text { firm-IV }\end{array}$ \\
\hline Reserve/GDP & $\begin{array}{l}-5.09 * * \\
{[2.19]}\end{array}$ & $\begin{array}{l}-11.8 * * \\
{[5.75]}\end{array}$ & $\begin{array}{l}0.5 \\
{[1.50]}\end{array}$ & $\begin{array}{l}2.09 \\
{[1.60]}\end{array}$ & $\begin{array}{l}-6.29 \\
{[6.91]}\end{array}$ & $\begin{array}{l}-6.11 \\
{[6.47]}\end{array}$ \\
\hline Reserve/GDP*DEP_WK & & & & $\begin{array}{l}-0.82 * * * \\
{[0.27]}\end{array}$ & & $\begin{array}{l}-0.79 * * \\
{[0.35]}\end{array}$ \\
\hline Reserve/GDP*DEP_INV & & & & $\begin{array}{l}0.077 \\
{[0.23]}\end{array}$ & & $\begin{array}{l}0.19 \\
{[0.26]}\end{array}$ \\
\hline M2/GDP & $\begin{array}{l}0.011 \\
{[0.016]}\end{array}$ & $\begin{array}{l}0.033 \\
{[0.024]}\end{array}$ & $\begin{array}{l}0.025 * * \\
{[0.011]}\end{array}$ & $\begin{array}{l}0.028 * * \\
{[0.011]}\end{array}$ & $\begin{array}{l}0.053 * \\
{[0.028]}\end{array}$ & $\begin{array}{l}0.061 * * \\
{[0.027]}\end{array}$ \\
\hline Domestic Credit/GDP & $\begin{array}{l}-0.0094 \\
{[0.010]}\end{array}$ & $\begin{array}{l}-0.021 \\
{[0.014]}\end{array}$ & $\begin{array}{l}0.0032 \\
{[0.0065]}\end{array}$ & $\begin{array}{l}0.0028 \\
{[0.0064]}\end{array}$ & $\begin{array}{l}-0.012 \\
{[0.016]}\end{array}$ & $\begin{array}{l}-0.016 \\
{[0.015]}\end{array}$ \\
\hline Foreign Debt/GDP & $\begin{array}{l}1.12 \\
{[0.90]}\end{array}$ & $\begin{array}{l}1.12 \\
{[0.93]}\end{array}$ & $\begin{array}{l}1.55^{* *} \\
{[0.78]}\end{array}$ & $\begin{array}{l}1.71 * * \\
{[0.75]}\end{array}$ & $\begin{array}{l}2.65^{*} \\
{[1.42]}\end{array}$ & $\begin{array}{l}3.02 * * \\
{[1.34]}\end{array}$ \\
\hline Financial Openness & $\begin{array}{l}-0.51 \\
{[0.31]}\end{array}$ & $\begin{array}{l}-0.51 \\
{[0.32]}\end{array}$ & $\begin{array}{l}-0.59 * * * \\
{[0.16]}\end{array}$ & $\begin{array}{l}-0.63 * * * \\
{[0.16]}\end{array}$ & $\begin{array}{l}-0.89 * * \\
{[0.35]}\end{array}$ & $\begin{array}{l}-0.98 * * * \\
{[0.33]}\end{array}$ \\
\hline Growth opportunity & & & $\begin{array}{l}0.16^{* * *} \\
{[0.048]}\end{array}$ & $\begin{array}{l}0.15 * * * \\
{[0.047]}\end{array}$ & $\begin{array}{l}0.12 * \\
{[0.060]}\end{array}$ & $\begin{array}{l}0.11^{*} \\
{[0.057]}\end{array}$ \\
\hline Firm size & & & $\begin{array}{l}0.065 \\
{[0.064]}\end{array}$ & $\begin{array}{l}0.073 \\
{[0.063]}\end{array}$ & $\begin{array}{l}0.037 \\
{[0.063]}\end{array}$ & $\begin{array}{l}0.043 \\
{[0.062]}\end{array}$ \\
\hline Tangibility & & & $\begin{array}{l}-0.66 * * * \\
{[0.24]}\end{array}$ & $\begin{array}{l}-0.57 * * \\
{[0.23]}\end{array}$ & $\begin{array}{l}-0.60 * * \\
{[0.27]}\end{array}$ & $\begin{array}{l}-0.49 * \\
{[0.25]}\end{array}$ \\
\hline Year fixed effects & $\mathrm{y}$ & $\mathrm{y}$ & $\mathrm{y}$ & $\mathrm{y}$ & $\mathrm{y}$ & $\mathrm{Y}$ \\
\hline Country fixed effects & $\mathrm{y}$ & $\mathrm{y}$ & $\mathrm{y}$ & $\mathrm{y}$ & $\mathrm{y}$ & Y \\
\hline Observations & 168 & 168 & 20948 & 19606 & 20766 & 19435 \\
\hline R-squared & 0.715 & 0.695 & 0.185 & 0.185 & 0.187 & 0.188 \\
\hline Number of firms & & & 4454 & 4152 & 4440 & 4141 \\
\hline
\end{tabular}


Table 10. The Impact of Reserve Accumulation on Idiosyncratic Stock Return Volatility

\begin{tabular}{|c|c|c|c|c|}
\hline & $\begin{array}{l}\text { Average } \\
\text { Effect }\end{array}$ & $\begin{array}{l}\text { Asymmetric } \\
\text { Effect }\end{array}$ & $\begin{array}{l}\text { Average } \\
\text { Effect IV }\end{array}$ & $\begin{array}{l}\text { Asymmetric } \\
\text { Effect IV }\end{array}$ \\
\hline Reserve/GDP & $\begin{array}{l}0.93 * * \\
{[0.46]}\end{array}$ & $\begin{array}{l}0.42 \\
{[0.55]}\end{array}$ & $\begin{array}{l}1.24 \\
{[1.11]}\end{array}$ & $\begin{array}{l}0.52 \\
{[1.09]}\end{array}$ \\
\hline Reserve/GDP*DEP_WK & & $\begin{array}{l}0.12 * \\
{[0.069]}\end{array}$ & & $\begin{array}{l}0.14^{*} \\
{[0.081]}\end{array}$ \\
\hline Reserve/GDP*DEP_INV & & $\begin{array}{l}0.22 * * * \\
{[0.053]}\end{array}$ & & $\begin{array}{l}0.27 * * * \\
{[0.060]}\end{array}$ \\
\hline Growth opportunity & $\begin{array}{l}0.01 \\
{[0.014]}\end{array}$ & $\begin{array}{l}0.011 \\
{[0.013]}\end{array}$ & $\begin{array}{l}0.012 \\
{[0.014]}\end{array}$ & $\begin{array}{l}0.013 \\
{[0.014]}\end{array}$ \\
\hline Firm size & $\begin{array}{l}-0.11 * * * \\
{[0.012]}\end{array}$ & $\begin{array}{l}-0.11 * * * \\
{[0.012]}\end{array}$ & $\begin{array}{l}-0.11 * * * \\
{[0.013]}\end{array}$ & $\begin{array}{l}-0.11 * * * \\
{[0.013]}\end{array}$ \\
\hline Profit & $\begin{array}{l}-0.17 * * * \\
{[0.047]}\end{array}$ & $\begin{array}{l}-0.18 * * * \\
{[0.047]}\end{array}$ & $\begin{array}{l}-0.17 * * * \\
{[0.047]}\end{array}$ & $\begin{array}{l}-0.18 * * * \\
{[0.046]}\end{array}$ \\
\hline Tangibility & $\begin{array}{l}0.14 * * * \\
{[0.034]}\end{array}$ & $\begin{array}{l}0.16 * * * \\
{[0.032]}\end{array}$ & $\begin{array}{l}0.14 * * * \\
{[0.036]}\end{array}$ & $\begin{array}{l}0.15 * * * \\
{[0.034]}\end{array}$ \\
\hline $\mathrm{M} 2 / \mathrm{GDP}$ & $\begin{array}{l}0.0025 \\
{[0.0027]}\end{array}$ & $\begin{array}{l}0.0022 \\
{[0.0027]}\end{array}$ & $\begin{array}{l}0.0012 \\
{[0.0051]}\end{array}$ & $\begin{array}{l}0.0017 \\
{[0.0048]}\end{array}$ \\
\hline Domestic Credit/GDP & $\begin{array}{l}-0.0016 \\
{[0.0016]}\end{array}$ & $\begin{array}{l}-0.0016 \\
{[0.0015]}\end{array}$ & $\begin{array}{l}-0.00083 \\
{[0.0029]}\end{array}$ & $\begin{array}{l}-0.0013 \\
{[0.0028]}\end{array}$ \\
\hline Foreign Debt/GDP & $\begin{array}{l}0.48 * * * \\
{[0.18]}\end{array}$ & $\begin{array}{l}0.50 * * * \\
{[0.17]}\end{array}$ & $\begin{array}{l}0.43 * \\
{[0.24]}\end{array}$ & $\begin{array}{l}0.49 * * \\
{[0.23]}\end{array}$ \\
\hline Financial Openness & $\begin{array}{l}-0.12 * * * \\
{[0.046]}\end{array}$ & $\begin{array}{l}-0.12 * * * \\
{[0.046]}\end{array}$ & $\begin{array}{l}-0.11^{*} \\
{[0.064]}\end{array}$ & $\begin{array}{l}-0.12^{*} \\
{[0.062]}\end{array}$ \\
\hline Observations & 20766 & 19829 & 20766 & 19435 \\
\hline R-squared & 0.173 & 0.174 & 0.167 & 0.174 \\
\hline Number of firms & 4440 & 4190 & 4440 & 4141 \\
\hline
\end{tabular}


Table 11. The Role of Foreign Ownership on Corporate Risk Taking

\begin{tabular}{lllll}
\hline & Leverage & Cash/Asset & $\begin{array}{l}\text { Risky } \\
\text { Investment }\end{array}$ & $\begin{array}{l}\text { Stock return } \\
\text { volatility }\end{array}$ \\
& & & & \\
Reserve/GDP & -0.038 & -0.02 & 0.0071 & 0.43 \\
(Reserve/GDP)* & {$[0.072]$} & {$[0.039]$} & {$[0.053]$} & {$[0.40]$} \\
$\quad$ Domestic ownership dummy & {$\left[0.24^{* * *}\right.$} & $-0.15^{* * *}$ & 0.013 & $1.25^{* * *}$ \\
Growth opportunity & {$[0.066]$} & {$[0.042]$} & {$[0.050]$} & {$[0.37]$} \\
Firm size & -0.001 & $0.010^{* * *}$ & $0.0057^{*}$ & 0.012 \\
& {$[0.0026]$} & {$[0.0015]$} & {$[0.0031]$} & {$[0.017]$} \\
Profit & $0.076^{* * *}$ & -0.00038 & $-0.013^{*}$ & $-0.092^{* * *}$ \\
Tangibility & {$[0.0062]$} & {$[0.0036]$} & {$[0.0068]$} & {$[0.014]$} \\
& $-0.30^{* * *}$ & $0.080^{* * *}$ & $-0.13^{* * *}$ & $-0.14^{* *}$ \\
M2/GDP & {$[0.022]$} & {$[0.0094]$} & {$[0.028]$} & {$[0.060]$} \\
& $0.16^{* * *}$ & $-0.35^{* * *}$ & $-0.069^{* * *}$ & 0.034 \\
Domestic Credit/GDP & {$[0.020]$} & {$[0.017]$} & {$[0.019]$} & {$[0.043]$} \\
& $0.0015^{* * *}$ & 0.00018 & 0.00032 & $0.0077^{* *}$ \\
Foreign Debt/GDP & {$[0.00042]$} & {$[0.00019]$} & {$[0.00042]$} & {$[0.0032]$} \\
Financial Openness & $-0.00077^{* * *}$ & 0.000044 & 0.00031 & -0.0015 \\
Firm and year fixed effects & {$[0.00023]$} & {$[0.00011]$} & {$[0.00025]$} & {$[0.0020]$} \\
Observations & $0.059^{* *}$ & $0.037^{* * *}$ & 0.017 & $0.51^{* * *}$ \\
R-squared & {$[0.024]$} & {$[0.011]$} & {$[0.018]$} & {$[0.19]$} \\
Number of firms & $-0.016^{* *}$ & $-0.011^{* * *}$ & -0.002 & $-0.15^{* * *}$ \\
\hline & {$[0.0068]$} & {$[0.0026]$} & {$[0.0063]$} & {$[0.043]$} \\
& Yes & Yes & Yes & Yes \\
& 13181 & 13172 & 12864 & 12259 \\
& 0.181 & 0.186 & 0.022 & 0.234 \\
& 2558 & 2557 & 2553 & 2415 \\
\hline
\end{tabular}


Table 12. The Role of Creditor Rights on Corporate Risk Taking

\begin{tabular}{|c|c|c|c|c|c|c|c|c|}
\hline & Leverage & Cash/Asset & $\begin{array}{l}\text { Risky } \\
\text { Investment }\end{array}$ & $\begin{array}{l}\text { Stock } \\
\text { return } \\
\text { volatility }\end{array}$ & Leverage & Cash/Asset & $\begin{array}{l}\text { Risky } \\
\text { Investment }\end{array}$ & $\begin{array}{l}\text { Stock } \\
\text { return } \\
\text { volatility }\end{array}$ \\
\hline \multirow[t]{2}{*}{ Reserve/GDP } & $0.28 *$ & $-0.47 * * *$ & -0.065 & $4.75^{* * *}$ & & & & \\
\hline & {$[0.15]$} & [0.058] & {$[0.085]$} & {$[0.84]$} & & & & \\
\hline Reserves/GDP & -0.042 & $0.11 * * *$ & 0.042 & $-1.24 * * *$ & & & & \\
\hline *Creditor Rights & [0.042] & {$[0.016]$} & {$[0.027]$} & {$[0.25]$} & & & & \\
\hline \multirow[t]{2}{*}{ Predicted Reserves } & & & & & $0.94 * * *$ & $-0.78 * * *$ & 0.094 & $3.70 * *$ \\
\hline & & & & & {$[0.24]$} & {$[0.11]$} & {$[0.17]$} & {$[1.74]$} \\
\hline Predicted Reserves/GDP & & & & & -0.025 & $0.094^{* * *}$ & 0.047 & $-0.92 * *$ \\
\hline${ }^{*}$ Creditor Rights & & & & & [0.044] & {$[0.021]$} & {$[0.030]$} & {$[0.36]$} \\
\hline \multirow[t]{2}{*}{ Growth opportunity } & 0.0032 & $0.012 * * *$ & -0.0024 & $0.028 * *$ & $0.0065^{* *}$ & $0.010 * * *$ & -0.0014 & 0.021 \\
\hline & [0.0029] & {$[0.0015]$} & {$[0.0031]$} & [0.012] & {$[0.0028]$} & [0.0016] & {$[0.0031]$} & {$[0.015]$} \\
\hline \multirow[t]{2}{*}{ Firm size } & $0.057 * * *$ & -0.0036 & $-0.016 * * *$ & $-0.10 * * *$ & $0.059 * * *$ & -0.0049 & $-0.015 * * *$ & $-0.10 * * *$ \\
\hline & {$[0.0052]$} & {$[0.0035]$} & {$[0.0051]$} & [0.013] & [0.0053] & {$[0.0034]$} & [0.0051] & {$[0.012]$} \\
\hline \multirow[t]{2}{*}{ Profit } & $-0.26 * * *$ & $0.063 * * *$ & $-0.100 * * *$ & $-0.14 * * *$ & $-0.26 * * *$ & $0.063 * * *$ & $-0.10 * * *$ & $-0.14 * * *$ \\
\hline & [0.018] & {$[0.0077]$} & {$[0.020]$} & {$[0.042]$} & {$[0.018]$} & {$[0.0078]$} & {$[0.020]$} & {$[0.042]$} \\
\hline \multirow[t]{2}{*}{ Tangibility } & $0.17^{* * *}$ & $-0.31 * * *$ & $-0.084 * * *$ & 0.048 & $0.16^{* * *}$ & $-0.31 * * *$ & $-0.086 * * *$ & 0.068 \\
\hline & [0.019] & {$[0.014]$} & [0.019] & {$[0.041]$} & [0.019] & {$[0.014]$} & [0.019] & {$[0.043]$} \\
\hline \multirow[t]{2}{*}{$\mathrm{M} 2 / \mathrm{GDP}$} & $0.0010 * * *$ & $0.00056^{* * *}$ & $0.00048^{*}$ & 0.00047 & $-0.0018 * * *$ & $0.0019 * * *$ & -0.00029 & 0.0026 \\
\hline & [0.00029] & {$[0.00020]$} & {$[0.00025]$} & {$[0.0028]$} & {$[0.00061]$} & [0.00033] & {$[0.00047]$} & [0.0055] \\
\hline \multirow[t]{2}{*}{ Domestic Credit/GDP } & $-0.00079 * * *$ & 0.000054 & $0.00056 * * *$ & $-0.0028 *$ & $0.00084^{*}$ & $-0.00079 * * *$ & $0.00098 * * *$ & -0.0027 \\
\hline & {$[0.00021]$} & {$[0.00010]$} & [0.00021] & {$[0.0016]$} & {$[0.00046]$} & {$[0.00020]$} & {$[0.00030]$} & {$[0.0032]$} \\
\hline \multirow[t]{2}{*}{ Foreign Debt/GDP } & $0.056 * * *$ & $0.050 * * *$ & 0.014 & 0.15 & $-0.053^{*}$ & $0.10 * * *$ & -0.016 & 0.29 \\
\hline & {$[0.021]$} & [0.012] & {$[0.018]$} & {$[0.17]$} & {$[0.030]$} & {$[0.018]$} & {$[0.026]$} & {$[0.25]$} \\
\hline \multirow[t]{2}{*}{ Financial Openness } & $-0.010^{*}$ & $-0.016 * * *$ & -0.0078 & -0.033 & $0.019 * *$ & $-0.030 * * *$ & 0.000098 & -0.07 \\
\hline & {$[0.0054]$} & {$[0.0036]$} & [0.0048] & [0.043] & {$[0.0074]$} & [0.0044] & {$[0.0067]$} & {$[0.066]$} \\
\hline Firm \& year fixed effects & Y & Y & $Y$ & $Y$ & $\mathrm{Y}$ & $\mathrm{Y}$ & $Y$ & $\mathrm{Y}$ \\
\hline Observations & 23715 & 23702 & 22992 & 22354 & 23715 & 23702 & 22992 & 22354 \\
\hline R-squared & 0.141 & 0.155 & 0.02 & 0.173 & 0.144 & 0.154 & 0.02 & 0.156 \\
\hline Number of firms & 5241 & 5240 & 5191 & 4530 & 5241 & 5240 & 5191 & 4530 \\
\hline
\end{tabular}




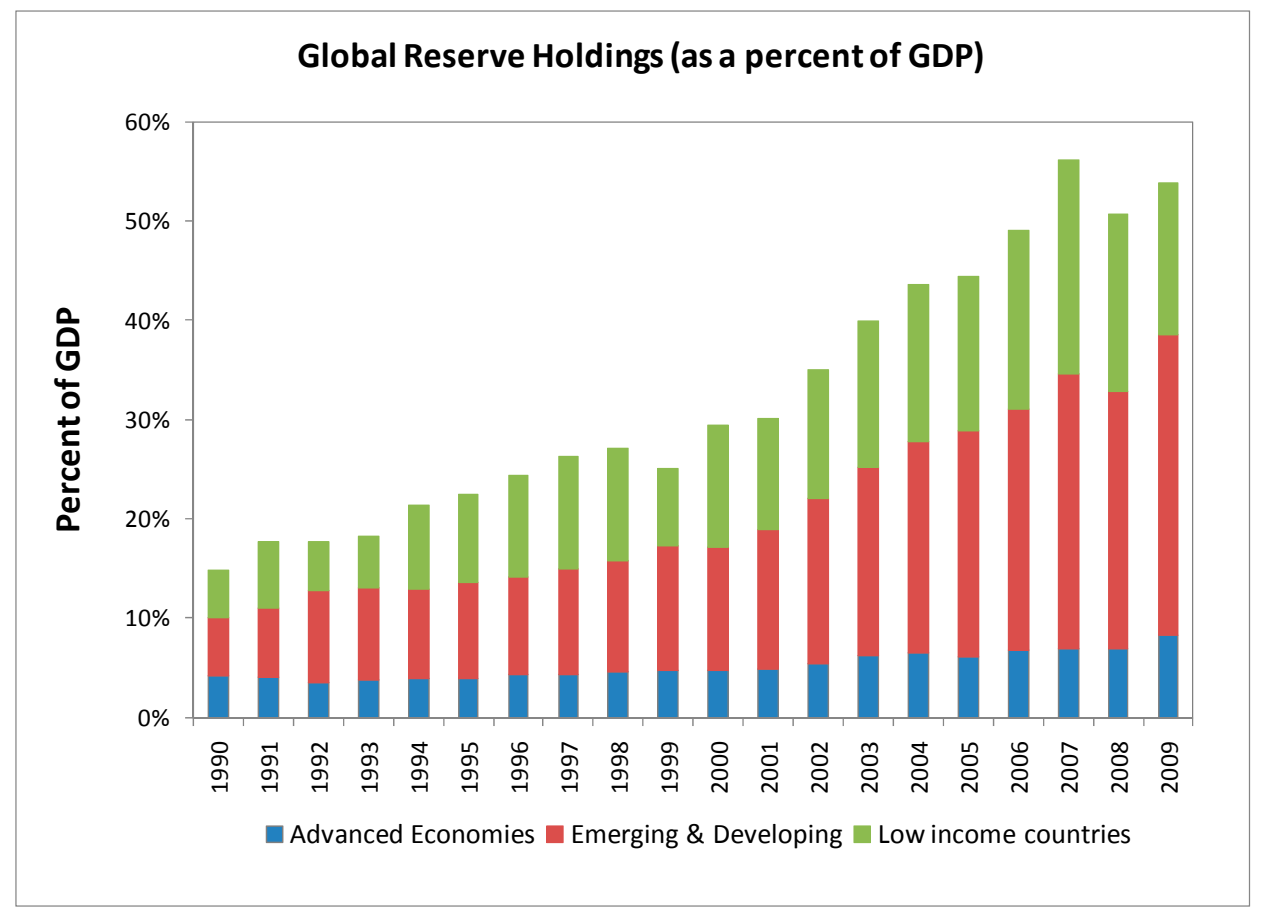

Figure 1: Foreign Reserve Holdings by Country Groups over 1993-2008

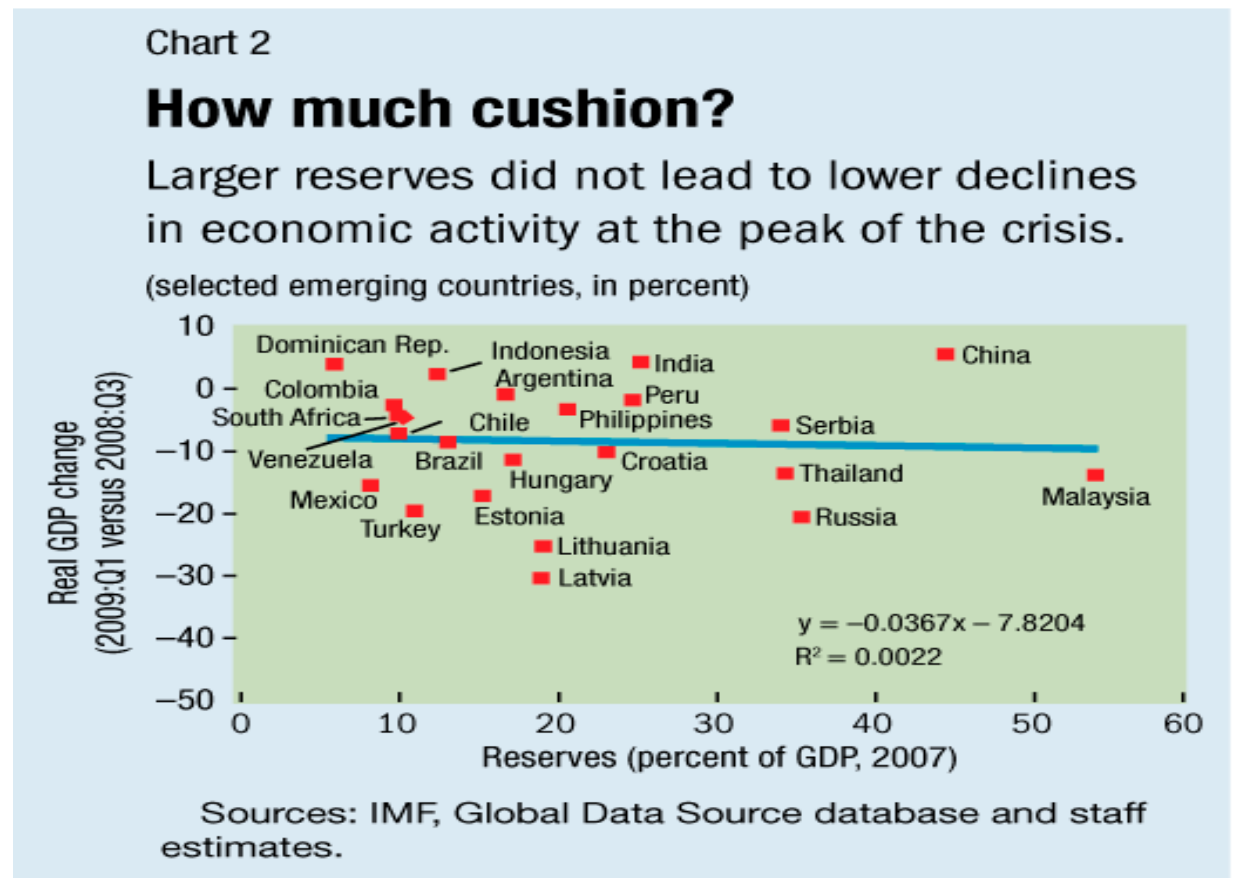

Figure 2: GDP Contractions During the Global Crisis versus the Pre-crisis Reserve Holdings Source: IMF Survey (2009) 


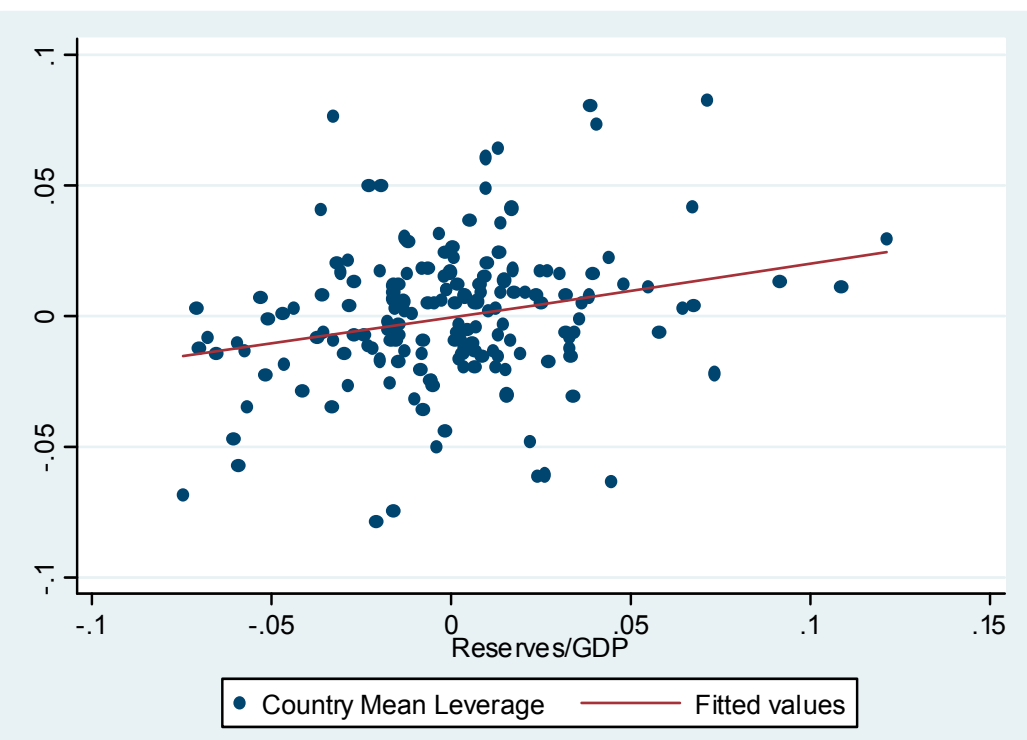

Figure 3: Average Leverage (over Firms in a Country-Year) against Reserve/GDP, Conditional on Country and Year Fixed Effects

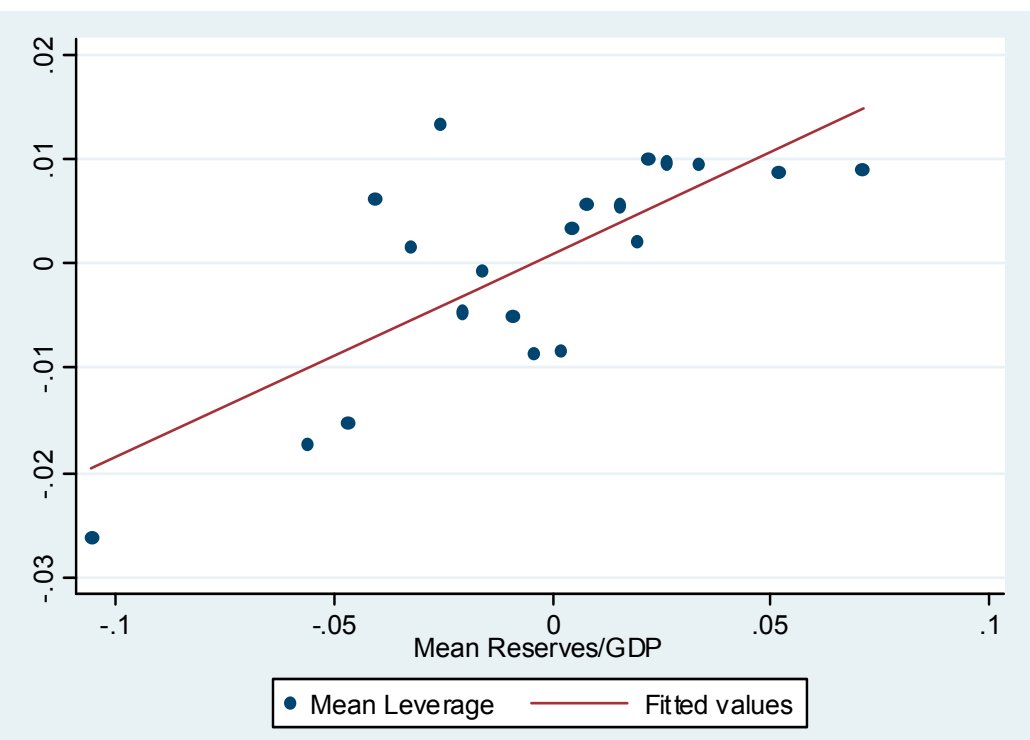

Figure 4: Average Leverage (for a Given Reserve/GDP Ratio) against Reserve/GDP, Conditional on Country and Year Fixed Effects

(Note: All observations, after taken out of country and year means, are first put into 20 quantiles based on the value of Rserve/GDP ratio. The average value of all leverage ratios in a grid is then plotted against the lower bound of the Reserve/GDP grid.) 


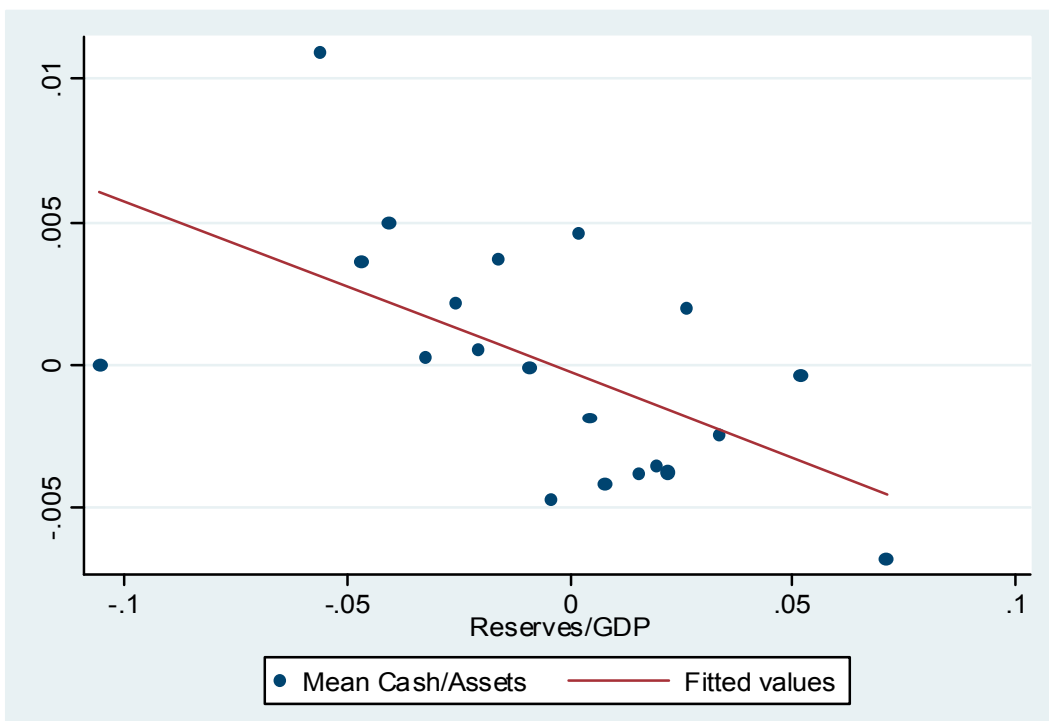

Figure 5: Average Cash/asset (for a Given Reserve/GDP Ratio) against Reserve/GDP, Conditional on Country and Year Fixed Effects

(Note: All observations, after taken out of country and year means, are first put into 20 quantiles based on the value of Rserve/GDP ratio. The average value of all cash/asset ratios in a grid is then plotted against the lower bound of the Reserve/GDP grid.)

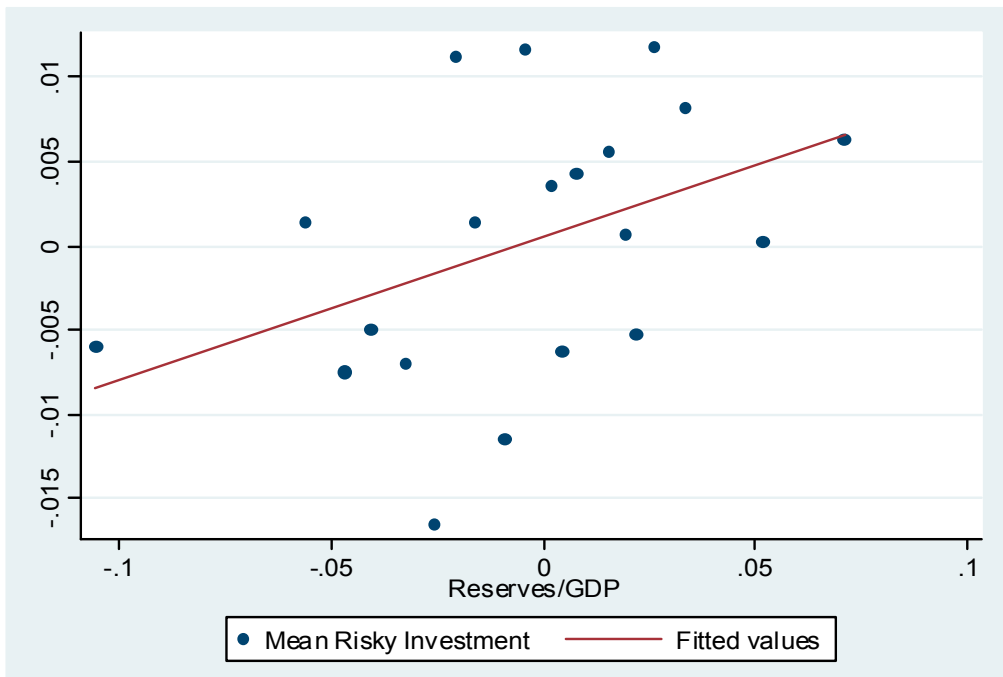

Figure 6: Average Risky Investment (for a Given Reserve/GDP Ratio) against Reserve/GDP, Conditional on Country and Year Fixed Effects

(Note: All observations, after taken out of country and year means, are first put into 20 quantiles based on the value of Rserve/GDP ratio. The average value of risky investment in a grid is then plotted against the lower bound of the Reserve/GDP grid.) 


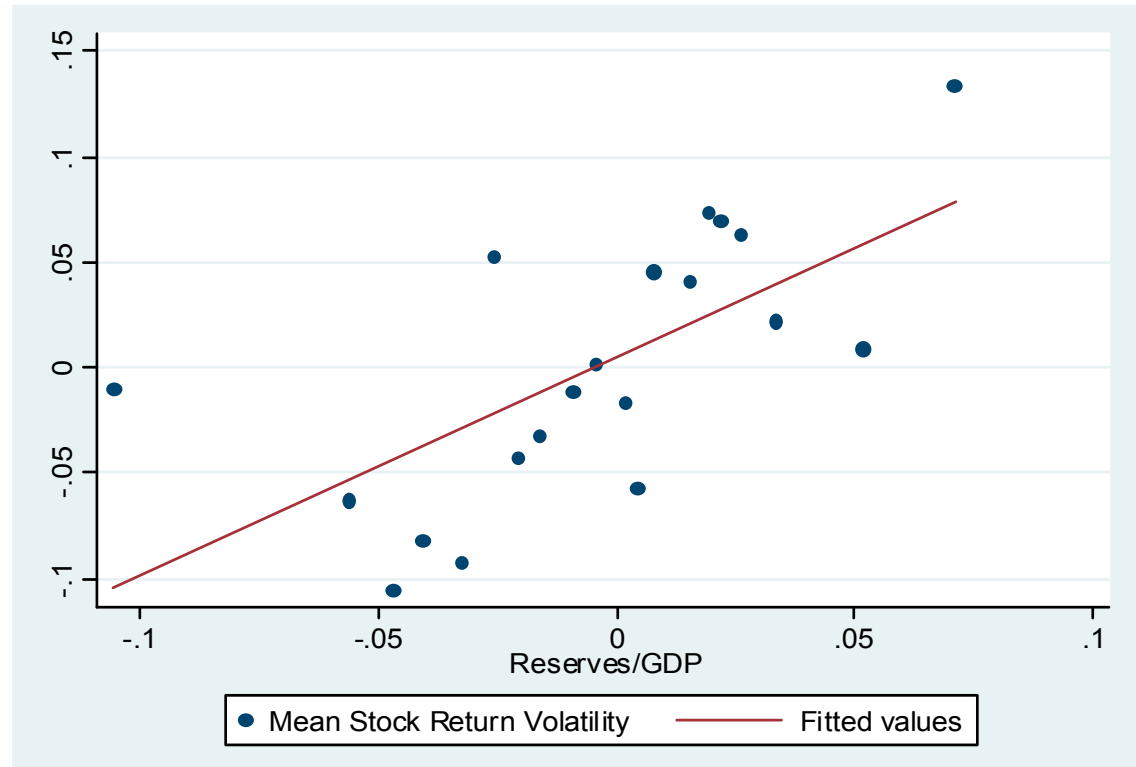

Figure 7: Average Stock Return Volatility (for a Given Reserve/GDP Ratio) against Reserve/GDP, Conditional on Country and Year Fixed Effects

(Note: All observations, after taken out of country and year means, are first put into 20 quantiles based on the value of Rserve/GDP ratio. The average value of all stock return volatility in a grid is then plotted against the lower bound of the Reserve/GDP grid.) 